\title{
Obchod s chudobou: kvalitativní obsahová analýza českých médií v letech 2006-2017
}

\author{
The Poverty Business: Qualitative Analysis \\ of Czech Media from 2006 to 2017
}

\section{Petr Kupka, ${ }^{*}$ Václav Walach, Alica Brendzová, Ondřej Plachý, Ĺubomír Lupták, Laco Toušek, Kateřina Tvrdá, Klára Vanková a Tereza Dvořáková}

Západočeská univerzita v Plzni

\begin{abstract}
The poverty business has recently become a frequent issue in public discourse. The Program Declaration of the Government of the Czech Republic also reflects this, as the poverty business is mentioned here in relation to the abuse of the welfare system through overpriced lodging houses. In spite of the political significance of the poverty business, the research on this issue has been scant. No attempt has even been made to clarify the meaning of this concept. This study is meant to be a first step in understanding the poverty business in the Czech context; it aims to explore how this phenomenon was represented in the Czech news media. The research was based on the theory of representation and qualitative content analysis, a method that was devised for thematic analysis of media content. The data were drawn from the Anopress IT database. Out of 1,277 texts containing the term "poverty business" and similar relevant terms, 66 texts were selected for the analysis. The analysis found that the poverty business is mainly presented as a matter of housing; however, other meanings were also identified, all of which were connected to the idea of exploitation of the poor and vulnerable segments of society. The victims of the poverty business include not only the clients of poverty entrepreneurs but also other people who were categorized according to their alleged decency or indecency. The consequences of the poverty business were seen as relating to clients, interethnic coexistence and the public administration. The main subjects identified in media communications were the state, municipality, and poverty entrepreneurs, who played the role of culprits, profiting subjects, and rectifiers. To conclude, the poverty business was represented as a highly politicized issue that concerns the misuse of housing benefits and is seen both as a socio-economic and ethno-cultural problem. The solution to the poverty business was mostly conceived as a technical intervention into the welfare system, ignoring the agency of the victims of the poverty business.
\end{abstract}

\section{Keywords}

poverty business, poverty industry, social exclusion, socially excluded localities, qualitative content analysis

\footnotetext{
* Corresponding Author: Petr Kupka, Katedra antropologie, Fakulta filozofická Západočeské univerzity v Plzni, Sedláčkova 15, 30614 Plzeň. E-mail: petrkupka.jr@gmail.com.
} 


\section{Úvod}

Obchod s chudobou dnes představuje jedno z nejdiskutovanějších témat vztahujících se k problematice sociálního vyloučení. K obchodu s chudobou se v médiích vyjadřují představitelé státu i samosprávy (např. Echo24.cz 2016; Denikreferendum.cz 2017), zástupci neziskových organizací (např. ČRo 2016), ale i lidé, kteří na obchodu s chudobou různým způsobem participují, at už jako investoři (např. iDnes.cz 2018a), nebo jako klienti (např. iDnes 2018b). O jeho významu pro veřejný diskurz svědčí i to, že se dostal do Programového prohlášení vlády, kde byl charakterizován jako př́íklad „zneužívání sociálního systému“ prostřednictvím „předražených ubytoven“ (Vláda ČR 2014: 13). Obchod s chudobou tedy představuje důležitý politický problém, $\mathrm{k}$ jehož řešení se zavázal vrcholný orgán výkonné moci. Navzdory tomu nebyl obchod s chudobou ze strany sociálních věd zatím př́liš reflektován.

To může být dáno i růzností významů, jichž pojem „obchod s chudobou “ ve veřejné rozpravě nabývá, a z toho plynoucími obtížemi při konstrukci objektu výzkumu. Z veřejného používání termínu „ochodu s chudobou“ je zřejmé, že zastupuje poměrně různorodý soubor praktik, od výnosného poskytování bydlení chudým (Jedináková, Pischová 2013: 29) po predátorské praktiky exekutorů namírené proti zranitelným částem populace (ČRo 2018). Obsahová rozmanitost, politická relevance a dosavadní absence sociálně-vědních prací nás vedla k tomu, abychom významy „obchodu s chudobou" hlouběji prozkoumali a pokusili se objasnit, co tento termín znamená. Jenom takto můžeme poznání o obchodu s chudobou dále promýšlet a srovnávat je s věděním o tomto fenoménu z jiných geografických kontextů, jak je prezentuje zahraniční sociálně-vědní literatura. V zahraničních studiích se pojem „obchod s chudobou“ používá v souvislosti s komerčními praktikami zacílenými na chudé a zranitelné vrstvy populace. Společným jmenovatelem těchto studií je identifikování vědomé orientace různých aktérů na tyto vrstvy a zneužívání práva k realizaci nemorálních forem podnikání.

V této studii chceme zjistit, o čem se mluví, když se mluví o obchodu s chudobou, a to v mediálním diskurzu. Média jsou totiž považována za důležitou platformu, v níž se utváří a vyjednávají dominantní významy společenských problémů a změn (Happer, Philo 2013). Mediální sdělení obsahující pojem obchodu s chudobou jsme identifikovali prostřednictvím databáze Anopress IT. Celkem jsme do našeho korpusu zařadili 1277 textů, přičemž ten vůbec první byl zveřejněn v roce 2006. ${ }^{1} \mathrm{~S}$ přihlédnutím $\mathrm{k}$ výše řečenému si jako svou výzkumnou otázku stanovujeme tuto: Jak byl reprezentován obchod s chudobou ve sděleních zveřejněných v českých zpravodajských médiích v letech 2006 až 2017 ?

Mediální sdělení jsme zkoumali pomocí kvalitativní obsahové analýzy. Obsahová analýza představuje „flexibilní metodologii“, kterou lze vymezit jako „systematický, rigorózní př́stup k analýze dokumentu získaných či vytvořených v průběhu výzkumu" (White, Marsh 2006: 22). Za flexibilní lze tuto metodologii označit proto, že v sobě skrývá natolik různorodé přístupy k analýze kvantitativních i kvalitativních dat, že lze v jejím případě hovořit o „širokém a dodnes neutřibeném pojeti “ (Dvořáková 2010: 95). K zodpovězení naší výzkumné otázky jsme se přidržovali kvalitativní obsahové analýzy, v níž jsou „kategorie převážně odvozeny z dat, aplikovány na data na základě pozorného čtení a analyzovány výhradně kvalitativně" (Forman, Damschroder 2008: 39).

Dříve než se dostaneme $\mathrm{k}$ tomu, jak jsme toto abstraktní vymezení převedli do analytické praxe, považujeme za nezbytné stručně představit teoretická a metodologická východiska našeho zkoumání. Z teoretického hlediska je studie zasazena do kontextu zatím nepř́liš početných kriminologických studií, které se v současnosti orientují zejména na prozkoumávání charakteru praktik obchodu s chudobou. Ústředním metodologickým konceptem je reprezentace, které rozumíme jako

\footnotetext{
${ }^{1} \mathrm{~V}$ analýze jsme hodlali analyzovat období od roku 1996 do dne stažení. První výstup obsahující termín obchod s chudobou však byl zveřejněn až 27.9.2006, texty pak byly staženy dne 26. 8. 2017. Ohraničení korpusů a závěry vyvozené z jejich analýzy se tedy vztahují $\mathrm{k}$ těmto dnům.
} 
„stěžejni součásti procesu, jímž jsou produkovány a šířeny významy mezi členy určité kultury“ (Hall 1997b: 15). Poté následuje kapitola věnovaná metodologickým aspektům studie. Zabýváme se v ní hlavně způsobem konstrukce našeho vzorku a postupem analýzy textů vybraných do tohoto vzorku. V rámci analýzy reprezentace obchodu s chudobou budeme zodpovídat otázky:

- Jaké konkrétní praktiky byly prezentovány jako obchod s chudobou?

- Jak byly líčeny jejich oběti?

- Jak byly prezentovány jejich di̊sledky?

- Jak byly konkrétní subjekty povolávány k zodpovědnosti za jejich existenci?

\section{Teoretická a metodologická východiska}

Mezi pojmem a praxí obchodu s chudobou existuje zásadní rozdíl. Praktiky obohacování se na chudých a zranitelných populacích, jak jsme si obchod s chudobou předběžně vymezili na základě našeho předporozumění formovaného nesystematickým vstřebáváním informací z nejrůznějších zdrojů, byly popsány již před mnoha lety, aniž by byly jako obchod s chudobou označovány. Jedním z prvních autorů, kteří se touto problematikou zabývali ve vztahu k poskytování bydlení, byl Friedrich Engels (1950). Ten ve svém mapování životních podmínek formující se dělnické třídy v anglickém městském prostředí upozornil mimo jiné na praxi zaměstnávání dělníků továrníky pod podmínkou, že zároveň budou bydlet v bytech jimi zřízenými. Jelikož byly tyto byty vybudovány poblî̌z továren, továrníci si tím zajištovali nejen větší jistotu a disponibilitu pracovní síly, ale také navrácení části mzdy zpět do svých rukou. Obecně pak pro tehdejší dělníky platilo, že platili nepoměrně vysoké nájmy za bydlení v neútěšných a často nehygienických podmínkách, přičemž vůbec nejhorší a mnohdy segregované bydlení obvykle měli irští přistěhovalci.

V kontextu českých sociálně vyloučených lokalit byly podobné praktiky také nejednou zaznamenány. Ve strategických dokumentech a výzkumných zprávách jsou zmiňovány „neúměrně vysoké nájmy“ (Rada vlády ČR 2012), „zneuživání sociálního systému na úkor klientĩ “ pronajímateli bytů (Kraj Vysočina 2012: 26), „zatajování skutečného stavu“ pronajímaných nemovitostí (ASZ 2014a: 21), „nevracení přeplatki̊ za energie“ (ASZ 2014b: 48), „násili vůči méně poslušným nájemnikưm, omezování svobody ubytovaných třeba zadržováním osobních dokladư " (Dvořáková 2015: 21) či "odkoupení práva užívat byt od nájemníků ve finanční tísni" a "fiktivní výměna bytü" (Rada vlády ČR 2015: 26-36). Ani v jednom z těchto případů však nebyly zarámovány jako obchod s chudobou. A totéž platí o obohacování se formou lichvy, poskytování „rychlých“ půjček na vysoký úrok, podvodného sjednávání pojistných smluv, hazardu, prodeje drog či prostituce (např. ASZ 2014b: 24-50; Pelikánová, Šmoldas 2014: 20; Rada vlády ČR 2015: 72).

V anglojazyčném kontextu pojednává pojem „obchod s chudobou“ (poverty business) či též „průmysl chudoby“ (poverty industry) o různých formách ekonomického vazalství, od predátorského úvěrování organizovaného velkými ekonomickými korporacemi (např. Hudson 2002) po odčerpávání státem poskytovaných financí určených na sociální péči prostřednictvím soukromých konzultantů (Hatcher 2016). Průmysl chudoby pak specificky odkazuje k závislosti pracujících chudých (working poor) na komerčních finančních službách, bez nichž nemohou uspokojovat své základní životní potřeby (Soederberg 2014). Uvedené studie obecně zdůrazňují vliv společenských nerovností na možnosti obohacování se mocnějších skupin obyvatel na těch nejzranitelnějších; na roli nerovnoměrného př́stupu k právu, který existenci těchto praktik dovoluje, aniž by to vyvolalo větší odpor na straně znevýhodněných; a na existenci mocenských forem, které společenské nerovnosti a nerovnoměrný přístup k právu dále prohlubují a reprodukují.

Jakkoli jsou tyto praktiky obchodu s chudobou legální, jejich zjevná společenská škodlivost z nich učinila předmět především kriminologického zájmu. Kritičtí kriminologové obecně upo- 
zorňují na často nejasnou hranici mezi legálním a ilegálním a také na to, že podobné jednání je u různých společenských skupin kriminalizováno odlišným způsobem (např. DeKeseredy 2010). Mocenská asymetrie mezi pachateli a jejich obětmi řadí téma obchodu s chudobou ke kriminologické tradici výzkumu tzv. kriminality bílých límečků (např. Friedrichs 2009). Tento typ kriminality obecně zastupuje jednání, při němž fyzické i právnické osoby požívající společenskou vážnost zneužívají důvěru v ně kladenou pro své vlastní obohacení (srov. Sutherland 1940). Výzkum kriminality bílých límečků v současnosti zahrnuje široké spektrum překračování zákona v oblasti vymáhání práv přes zdravotnictví, vzdělávání a životní prostředí až po bydlení. V souvislosti s bydlením byla pozornost věnována i nemorálnímu pronajímání bydlení (slumlordism) (např. Payne 2016: 194-216, srov. Lind, Blomé 2012; Uitermark, Loopmans 2013). Zdá se tedy, že praktiky obchodu s chudobou tak, jak jsou tematizovány v ČR, by mohly do této oblasti výzkumu spadat. Tento předpoklad je však nutné potvrdit.

V této studii nás tedy zajímá, o čem výraz „obchod s chudobou“ pojednává, respektive co tento pojem reprezentuje. Stuart Hall (1997b: 17) definoval reprezentaci jako „produkci významu konceptů v našich myslích skrze jazyk". Odklonil se přitom od tradičního náhledu, který reprezentaci chápal jako více či méně přesnou reflexi či vylíčení nějakého objektu. Zastával konstruktivistický přístup, v němž je reprezentace jazykovým aktem, jímž se objekt obdařuje významem. Význam určitého objektu není totiž „přirozeně“ dán jeho vlastnostmi či konstitucí, ale je ustanoven politicky. Kámen může být nejenom kamenem, ale také ukazatelem hranice či uměleckou sochou. Významy nejsou nacházeny, ale ve skutečnosti konstruovány. A tyto konstrukce pochopitelně existují v množném čísle. Která z nich převáží, který význam objektu se upevní, to je otázkou moci a interpretace (srov. Hall 1997a).

Obchod s chudobou je jedním z konceptů, které nám umožňují odkazovat k „reálnému“ či imaginárnímu světu objektů. Z hlediska saussurovské lingvistiky se jedná o znak, který sestává ze dvou složek. Tou první je signifikant (označující), který odpovídá skupině písmen či zvuku vydávanému při vyslovování určitého slova. Druhou složkou znaku je signifikát (označovaný) neboli mentální koncept, který je obrazně spojený se signifikantem. Vztah mezi nimi je ovšem arbitrární. To znamená, že vyžaduje určitou sociální fixaci, aby si interpretující představili pod slovem „strom“ rostlinu s kmenem a větvemi (srov. de Saussure 2007; Procter 2004: 41). Na rozdíl od stromu je obchod s chudobou abstraktní koncept. To však neznamená, že by neoznačoval určitý mentální konstrukt. O jaký konstrukt (signifikát) se jedná ve světě mediálních výstupů a co tento konstrukt reprezentuje, to se pokoušíme zjistit kvalitativní obsahovou analýzou.

Obsahová analýza vznikla původně za účelem analýzy kvantitativních dat v mediálních studiích ve dvacátých letech 20. století, nicméně již od padesátých let se rozvíjí kvalitativní obsahová analýza jako její alternativa. Za její hlavní definiční znak lze považovat to, že na rozdíl od kvantitativní obsahové analýzy nevytváří analytické kategorie deduktivně, ale spíše induktivně, a že tyto kategorie jsou pak používány při kódování textu prostřednictvím jeho pozorné četby. To znamená, že kvalitativní obsahová analýza pracuje zpravidla s menším počtem analyzovaných textů či jiných mediálních výstupů než ta kvantitativní. Jako tomu je u každého kvalitativního výzkumu, také v případě kvalitativní obsahové studie platí, že jejím cílem je „porozumèt určitému fenoménu spiše než vytvářet zobecňující závěry pro celou populaci ze studovaného vzorku na základě statistické inference" (Forman, Damschroder 2008: 41).

Podle Brymana (2004: 392) je kvalitativní obsahová analýza „pravděpodobně nejrozšířenějším př́stupem ke kvalitativní analýze dokumentư“, přičemž spočívá ve „vyhledávání stěžejních témat $v$ analyzovaném materiálu". Pro určení významnosti těchto témat je zásadní kontext, v němž se tato témata nacházejí. Lze považovat za vhodné, aby analýza začala nejprve přečtením celého korpusu a teprve poté se přistoupilo ke kódování jednotlivých dokumentů. Obsahová analýza může obecně sloužit různým účelům (Smith 2000). V našem případě se jedná o exploratorní výzkum, 
nebot významu obchodu s chudobou nebyla prozatím věnována výzkumná pozornost a nikdo se dosud nepokusil tento pojem definovat, ač se v posledních letech pravidelně objevuje na stránkách médií. Aplikaci kvalitativní obsahové analýzy ukazuje následující kapitola.

\section{Realizace výzkumu}

Při tvorbě datového souboru jsme využili databázi Anopress IT, která obsahuje sdělení publikovaná v různých zpravodajských médiích. Vlastní soubor jsme sestavili tak, že jsme do databáze zadali klíčová slova jako „obchod s chudobou“, „byznys s chudobou“ a „podnikání s chudobou", včetně jejich morfologických variací. Všechny získané texty jsme zařadili do korpusu. Po odstranění výstupů pocházejících z jiných než zpravodajských médií jsme celkem disponovali 1277 mediálními sděleními, která byla publikována v médiích různého geografického zaměření, typu, periodicity a vlastnictví.

Pro samotnou analýzu jsme se rozhodli vybrat texty např́ič celým sledovaným obdobím. Předpokládali jsme, že se obraz obchodu s chudobou postupem času proměňoval, a tak jsme vzali v potaz nerovnoměrné rozložení výstupů. V letech 1996-2005 se pojem „obchod s chudobou“ v českých médiích neobjevil. V období 2006-2012 bylo zveřejněno pouze 24 relevantních textı̊, do analýzy jsme je tedy zahrnuli všechny. Texty z let 2013 až 2017 jsme vybrali na základě proměny zastoupení sledovaných kategorií slov. Pomocí frekvenční analýzy² jsme nejprve identifikovali texty obsahující kategorie, které v daném období zaznamenaly největší kvantitativní změnu v zastoupení v mediálních sděleních. Jednalo se o kategorie jako „legislativa“, „kriminalita“, „Romové“, „ubytovny“, „státní správa“ a „samospráva“. Tento způsob vytváření vzorku zajistil, že byl analyzován obsah 42 textů, které lze považovat za určující pro mediální diskurz o obchodu s chudobou, a to ve smyslu pokrytí jeho klíčových témat z hlediska vývoje v čase. Kritériem vzorkování byla kombinace obsahové rozmanitosti s pragmatickými možnostmi; kvalitativní obsahová analýza pojme pouze omezený počet textů. Celkem bylo analyzováno 66 textů, tj. $5 \%$ všech sdělení. ${ }^{3}$

K samotné analýze textu jsme přistoupili induktivně prostřednictvím programu pro analýzu kvalitativních dat MAXQDA 11. V první fázi analýzy bylo ve studovaném korpusu identifikováno 67 témat, přičemž bylo okódováno celkem 945 segmentů textů. V druhé fázi byla tato témata podřazena čtyřem kategoriím, jimž svým obsahem odpovídala. Kategorie „předmět“ zahrnuje typy komerčních praktik prezentované jako obchod s chudobou a interpretace té klícové z nich, tj. poskytování bydlení. Tím se však problematika obchodu s chudobou nevyčerpává. Spolu s praktikami byly často $\mathrm{v}$ této souvislosti diskutovány skupiny obyvatel, na něž tyto praktiky nejvýrazněji dopadly, společenské dopady, které měl obchod s chudobou mít, a také aktéři, kteří měli být zodpovědní za existenci tohoto typu podnikání. Tato tři témata jsme kategorizovali jako „oběti“, „důsledky“ a „subjekty“.

Ve třetí fázi bylo analyzováno každé téma jednotlivě za účelem specifikování jeho aspektů. Např́ḱlad téma „obchodník s chudobou“ má následující aspekty: „podinvestovanost nemovitostí“, „orientace na znevýhodněnou populaci“, „nadhodnocené nájemné“ a „vysávání státního rozpočtu“. Zatímco tedy kategorie je situována nejvýše na žebřičku abstrakce, téma se nachází o přičku níže a aspekty jsou vůbec nejníže. Jinak řečeno, analýza byla provedena na třech úrovních: kategorie, sub-kategorie a sub-sub-kategorie. Tyto úrovně tvoří i strukturu následující kapitoly. Všechny tři fáze byly realizovány jedním výzkumníkem, aby byla zajištěna koherence celého postupu.

\footnotetext{
${ }^{2}$ Frekvenční analýzu obsahu mediálních sdělení podrobněji popisujeme v jiné studii, viz Kupka et al. (2018).

${ }^{3}$ Seznam analyzovaných textů je $\mathrm{k}$ dispozici v př́loze této studie.
} 


\section{Empirická analýza}

\section{Praktiky}

Předmět obchodu s chudobou byl v analyzovaných textech chápán pěti různými způsoby. Ve většině sdělení převládalo chápání obchodu s chudobou ve smyslu (1) poskytování bydlení lidem pobírajícím sociální dávky na bydlení v bytových domech, na ubytovnách, ale i v jiných nemovitostech původně neurčených $\mathrm{k}$ bydlení. Spojení obchodu s chudobou s bydlením bylo přítomno již v prvním výstupu - rozhovoru MF Dnes s Ivanem Gabalem, majitelem výzkumné agentury Ivan Gabal Analysis \& Consulting, z 27.9.2006. Rozhovor se týkal životních podmínek romské populace v ČR. Při otázce na vznik vyloučených lokalit, které jeho firma poprvé v roce 2006 zmapovala, hovořil Gabal o obchodu s chudobou s ohledem na privatizaci bytového fondu: „Taky tu byla privatizace bytového fondu - to je obrovský byznys s chudobou." Pojem „byznys s chudobou" v článku bohužel nijak nedefinoval, ani s ním dále nepracoval.

V letech 2007-2012 konkurovalo tomuto chápání obchodu s chudobou (2) poskytování vysokoúročených nebankovních půjček a následné vymáhání dluhů prostřednictvím soukromých exekutorských úřadů nebo netransparentních rozhodčích řízení. Tato operace byla prezentována jako sázka na neschopnost dlužníka včas splácet, čímž docházelo k nárůstu poplatků z prodlení, a to až nad hodnotu původního dluhu. Exekuce na sociální dávky pak měla zajištovat věřitelům „doživotní ,rentu““ (MF Dnes 2007b). Tento význam obchodu s chudobou vnesli do mediálního prostoru pracovníci organizace Člověk v tísni.

Obchod s chudobou byl později používán i v dalších významech, jako bylo (3) provozování heren a kasin v oblastech se zvýšenou koncentrací chudých obyvatel, (4) poskytování práce „na černo", případně (5) kriminální aktivity zneužívající nouzi chudých obyvatel: lichva, prostituce, drogy a obecně organizovaný zločin. Všechny podnikatelské praktiky spojovala jejich orientace na chudé obyvatelstvo pobírající dávky systému státní sociální podpory a/nebo dávky pomoci $\mathrm{v}$ hmotné nouzi.

V průběhu sledovaného období se používání termínu obchod s chudobou ustálilo na poskytování bydlení osobám nebo rodinám pobírajícím příspěvek nebo doplatek na bydlení a takto jej budeme dále analyzovat. Jednak je k tomu relativně nejvíce informací v analyzovaných textech, jednak je oblast bydlení, jak bylo uvedeno výše, klíčová také pro zahraniční kriminologické studie. Ostatní formy obchodování s chudobou byly prezentovány obvykle jako doprovodné nebo související jevy systému s těžištěm v podnikání s pronajímáním nemovitostí chudým. Celkově byl obchod s chudobou prezentován jako soubor podnikatelských praktik založených na morálně zavrženíhodných předpokladech nebo způsobujících značnou sociální újmu.

Ve zbývající části kapitoly analyzujeme tyto praktiky jako „parazitování“ a „vykořistování“. Tyto kategorie reprezentují újmu, kterou způsobují: parazitování způsobuje újmu státu, vykořistování újmu klientům. Kromě těchto kategorií jsme dále v analyzovaných textech identifikovali kategorii „normální podnikání“, jež se snaží výše uvedené negativní atributy neutralizovat.

Pojímání obchodu s chudobou jako parazitování bylo založeno na zdůrazňování zneužívání systému sociálního zabezpečení poskytovateli bydlení. Obchod s chudobou byl v tomto případě prezentován jako mechanismus přesouvání finančních prostředků z veřejného rozpočtu do rukou podnikatelů prostřednictvím poskytování bydlení v nedůstojných a zanedbaných nemovitostech ikonicky označovaných jako ubytovny. Př́kladem může být úvodní věta z článku „Byznys s chudobou stojí Česko miliardu měsíčně. Živí pouze spekulanty“ (iDnes.cz 2014):

Dávky vyplácené na bydlení vzrostly za poslední rok o čtvrtinu, profitují z nich zejména majitelé ubytoven. Byznys s chudobou se obce snaží omezit: kupují ubytovny nebo nabízejí tréninkové byty. 
Vykořistování naproti tomu zdůrazňovalo zneužívání znevýhodněných skupin obyvatelstva k vlastnímu obohacení. Obchod s chudobou byl takto prezentován jako podnikatelská aktivita zneužívající omezené možnosti volby diskriminovaných, nevzdělaných a politicky bezmocných, jimž je možné poskytovat za vysoké částky nuzné bydlení za hranicí důstojnosti. Podobně jako u předchozí kategorie, i zde je hlavní ikonou takto prezentovaného podnikání ubytovna. Tento rámec ilustruje citace tehdejšího ředitele Agentury pro sociální začleňování Martina Šimáčka v pořadu Hyde park (С̌T 2015a):

V České republice se více než 100 tisíc lidí propadlo do těch takzvaných chudinských ubytoven. Vlastně ten trh s byty je vytlačil do nějakého segmentu, který je spíše zatížen nějakým byznysem s chudobou, nějakým vyděláváním na chudých, to se obecně ví, to jsou ti, kteří vlastně získávají sociální dávky na to, aby ubytovávali za předražené ceny ty nejchudší, protože trh s bydlením tyhle lidi nezachytil, to ve Skotsku neuvidíte.

V datech se objevilo i pojetí, jímž do mediálního diskurzu pronikal hlas obchodníků s chudobou. Ti byli v těchto výstupech označováni jako „realitní makléři“, „provozovatelé ubytoven“ nebo i „správci bytů pro sociálně slabé“. Poskytování bydlení chudému obyvatelstvu pobírajícímu dávky na bydlení bylo prezentováno jako standardní podnikatelská aktivita zaměřená na populaci, o kterou nemá nikdo zájem. Morální vina je zde přenášena z obchodníků s chudobou na jejich klienty, přičemž je upozorňováno na jejich údajné zneužívání sociálního systému, spočívajícího v upřednostnění pobírání dávek před prací. Takto o podstatě obchodování s chudobou hovořila „správkyně bytů i pro sociálně slabé v Mostě a Chomutově“ v pořadu Máte slovo (ČT 2017a):

Protože z naší praxe $80 \%$ lidí, kteří dávku na bydlení pobírají, by ji vůbec pobírat nemuseli, kteří by si na tu dávku mohli vydělat, a oni si opravdu vydělávají, ale na černo, a tak si zvyšují vlastně svoji rodinn... nebo svůj rodinný rozpočet na úkor lidí, kteří pracují a dávku teda nevyužívají. Dle mého názoru by dávku měli využívat úplně jiný lidé. A to např́ḱlad, jestli teda $\mathrm{k}$ tomu můžu ještě něco říct, například teda invalidé, opravdu osamělé matky, ne které matky si jenom na to hrají, dále potom senioři, kteř́i jsou opuštěný a fakt na to nemaj, a potom mladí lidé, kteří odcházejí např́ḱlad z dětských domovů a nemaj vlastně žádnou záštitu v rodině.

\section{Oběti}

Oběti obchodu s chudobou nezahrnují pouze klienty obchodníků s chudobou, ale také skupiny obyvatel, kteří jsou těmito podnikatelskými praktikami nepř́mo viktimizováni. A to at zhoršením kvality života, nebo menším objemem peněz určených jejich základním životním potřebám. Oběti byly v naprosté většině představovány jako chudí, případně jako „sociálně slabí" nebo „sociálně potřební“. Byly vyobrazovány prostřednictvím materiálního nedostatku nebo projevů nedůvěry v okolní svět, který je prý vystavil predátorským praktikám soukromých podnikatelů. Zároveň bývaly asociovány s požitkářstvím, rodinnými vazbami nebo etnickou jinakostí.

Oběti obchodu s chudobou však nepředstavovaly morálně neutrální kategorii, a i do jejich konstrukce byla projektována představa tzv. ideální oběti. Ideální obětí zde představuje kategorie jednotlivců, kterým je připisován „dokonalý a legitimní status oběti" (Christie 1986: 18). V souvislosti s obchodem s chudobou lze rozeznat několik figur, které lze dále rozlišit podle toho, zda byl jejich status oběti v médiích prezentovaný jako oprávněný či ne. To v praxi znamená, zda se oběti obchodu s chudobou staly souhrou okolností či neštastnou náhodou anebo se na něm alespoň zčásti samy podílely. Do první kategorie řadíme starousedlíky, seniory, matky samoživitelky, 
invalidy a nízkopř́ijmové rodiny. Můžeme je nazvat jako „slušné chudé oběti“. Do druhé kategorie pak spadají nezaměstnaní a nepřizpůsobiví, ${ }^{4}$ což jsou „oběti chudé a neslušné“.

Rozlišení na slušné a neslušné oběti má blízko ke klasické distinkci mezi sociálně potřebnými a nepotřebnými (deserving and underserving poor, srov. Katz 2013). Zatímco "slušné chudé oběti“ za svůj úděl nemohou, a tak si zaslouží pomoc společnosti, „neslušné chudé oběti“ si za své postavení mohou samy, a proto by si také samy měly pomoci. Figury dlužníků a Romů se nacházejí uprostřed mezi těmito dvěma póly.

Ústřední figurou slušných chudých obětí jsou starousedlíci. Figura starousedlíků jednotlivce nebo skupiny obyvatel, kteří v místech zasažených obchodem s chudobou nebo blízkém okolí žili dávno před jeho nástupem. Starousedlíci byli obvykle popisováni jako zprvu nezúčastnění, ale později silně poznamenaní pozorovatelé proměny lokalit, do nichž se vlivem obchodníků stěhovali noví sousedé - zpravidla prezentovaní jako problémoví, at už z důvodu své odlišné etnicity, nebo různých forem asociálního chování jako vandalismu či fyzického násilí. Starousedlíci naopak vystupovali v roli znepokojených jednotlivců, jimž není situace v lokalitě lhostejná a kteří požadují její aktivní řešení.

Kategorie starousedlíka čelícího zhoršené bezpečnostní situaci však byla místy vyvažována pojetím starousedlíka, jenž strach z kriminality zažívá nepřiměřeně k jeho reálnému stavu. Není to tedy tak pozitivní figura, jak by se mohlo na první pohled zdát. To je patrné např́íklad z reportáže z ústecké čtvrti Krásné Březno, jež na tento iracionální aspekt starousedlíka poukazuje (Týden 2013):

Z bývalé tříhvězdičkové depandance známého ústeckého hotelu Vladimir se postupně stala ubytovna pro dělníky a dnes ji obývají převážně Romové vystěhovaní z okolních ghett. Starousedlíci z nich mají strach, který jde někdy za hranice racionálního uvažování. „Tam, v bývalém Vladimiru, je to úplně nejhorší, “ ř́íká paní Zdena, která o pár ulic dále venčí malého pudla. Co konkrétně jí vadí? „To já ani nevím. Já tam radši nechodím."

At už byly důvody ke znepokojení starousedlíků líčeny jako racionální, nebo ne, starousedlíci byli primárně prezentováni jako nositelé aktérství. To znamená, že proti důsledkům obchodu s chudobou aktivně politicky vystupovali - například organizovanými protesty či jiným vynucováním opatření od místní samosprávy. Tato figura tedy reprezentuje jednotlivce přihlížející materiálnímu a symbolickému úpadku svého okolí, ale zároveň mající odhodlání a kapacity se s těmito dopady utkat.

Figury seniorů, matek samoživitelek, invalidů a nízkopř́ijmových rodin reprezentují nejzranitelnější části české populace, které se obětmi obchodu s chudobou už staly, př́ípadně hrozí, že se jimi v blízké budoucnosti stanou. Obětmi se mohou stát také tak, že jsou sociální dávky odčerpávány obchodníky s chudobou ve prospěch „neslušných chudých “, respektive na úkor těch, kteří je mají skutečně potřebovat. Senioři bývali charakterizováni jako osamělé osoby, které celý život pracovaly, ale důchod jim nestačí na zaplacení celého nájmu, a proto jsou nuceni využívat služeb obchodníků s chudobou a svůj nájem hradit z dávek na bydlení. Finanční nesnáze a pasivní přijímání svého údělu byly spojovány i s ostatními figurami uvedenými v první větě tohoto odstavce.

Kromě toho jsou pro tyto figury specifické dvě funkce. Zaprvé, především politiky byly stavěny do protikladu vůči neslušným chudým, aby zdůraznili jejich oprávněný nárok na př́jem sociální podpory na jedné straně a nespravedlnost pramenící z bydlení v substandardních podmínkách

\footnotetext{
${ }^{4}$ Výraz „nepřizpusobiví“ je silně stigmatizující a v případě, kdy je využíván jako kód pro Romy, jej lze považovat přímo za rasistický. Blíže k tomu viz Walach (2016: 86-92). V této studii výraz chápeme jako rétorickou figuru a používáme ji k analytickému účelu stejně jako figury nezaměstnaných, dlužníků a jiných. Proto je v textu uváděna jednotně bez uvozovek.
} 
lokalit organizovaných na způsob obchodu s chudobou na straně druhé. Tento kontrast ilustruje např́ḱklad výrok Michaely Marksové, tehdejší ministryně práce a sociálních věcí (ČT 2015b):

My chceme třístupňový systém bydlení, kde ti lidé úplně, kteří nemají ted'ka žádné návyky nebo jsou skutečně v úplně katastrofální situaci, nevědí, co sami se sebou, zůstanou v tom nejhorším typu, dejme tomu na úrovni dnešních lepších ubytoven... [...] Ale také bych ráda řekla, že my mluvíme i o seniorech, mluvíme o matkách samoživitelkách s dětmi. A tam samozřejmě není žádný důvod, aby takoví lidé, kteří nepotřebují sociální práci, zůstávali někde v ubytovnách.

Zadruhé, tyto figury sloužily k nabourání dominantního obrazu sociálně vyloučených lokalit a ubytoven jako etnicky homogenních míst. To znamená, že tyto figury byly v promluvách různých mluvčích užívány jako doklad toho, že obětí obchodu s chudobou se mohou stát nejen Romové, ale v podstatě kdokoli, kdo se ocitne bez dostatečného př́ijmu.

Dlužníci představovali figuru spojující charakteristiky slušných a neslušných chudých. Pokud bylo zadlužení prezentováno jako důsledek ztráty práce a nutnosti obstarat si za každou cenu příjem, byla figura dlužníků používána spíše jako figura reprezentující nespravedlivé dopady ekonomických a politických rozhodnutí a nekontrolovaného působení lichvářů. Figura dlužníka v takových případech dlužila často obchodníkům s chudobou.

Zadlužení však bylo konstruováno i jako osobní volba, které mohlo být předejito zodpovědným chováním. Předpokládalo se, že kdyby se dlužníci chovali lépe, neměli by dluhy na nájemném a energiích. V tomto případě byli dlužníci chápáni jako zadlužení vlastní vinou či zaslouženě. Nejčastěji dlužili obci či společnostem poskytujícím elektřinu, plyn, vodu apod. Typickým příkladem posuzování způsobu zadlužení je citace zastupitele Libora Štástky, který v reportáži „Sociální byty v Brně“ podmiňoval řešení obchodu s chudobou rozlišováním mezi dlužníky (ČT 2016):

[Strategie pro sociální začleňování] obsahuje takové šílené věci jako rozdávání bytů zdarma, jako zdarma městskou hromadnou dopravu pro sociálně nezačleněné. To jsou věci, které nemůžou podle mého názoru fungovat, a vy jste položila správný dotaz, jestli to je motivační. No samozřejmě, že není, protože pro lidi, kteří si plní své povinnosti, platí nájem, př́ípadně mají dluhy a splácí je, tak se vedle nich ocitne rodina, která zanechala například 300 tisícový dluh, a město najednou přijde a dá jí byt. A ani nechce.

Romové byli prezentováni pomocí dvou schémat. To první je líčí jako hlavní oběti obchodu s chudobou, jimiž se stali v důsledku svého nepříznivého postavení v české společnosti po roce 1989, daného zejména dlouhodobou nezaměstnaností a rozšsiřenou diskriminací v různých oblastech života, především na trhu s bydlením a pracovním trhu. Tato situace vytváří z mnoha Romů příjemce dávek na bydlení, což z nich dělá terč obchodníků s chudobou. Druhé schéma spojuje nezaměstnanost s požitkářským životním stylem, jenž se vyznačuje hlučností, potulkou a navazujícím rizikovým chováním (užívání drog, delikvence aj.). Zde Romové už nevystupují pouze jako pasivní oběti, ale i jako aktivní strůjci zločinu a provokace. Ilustruje to článek o obavách obyvatel severočeského města Tanvaldu z přistěhování dalších Romů do města vlivem obchodu s chudobou (MF Dnes 2014b):

Obyvatelé Tanvaldu se bojí, že u nich bude velká chudinská ubytovna pro Romy. Opuštěný internát zkrachovalé společnosti Seba T získal v dražbě nový majitel [...] Železobetonový internát stojí v Tanvaldě od roku 1965 a ukrývá se v něm 80 pokojů, společná umývárna, WC a kuchyňka. „Bojíme se, že se do města přistěhují další Romové," prohlásil muž z Tanvaldu, který si kvůli obavám o svou bezpečnost nepřál být jmenován. „Už ted’ tady jde strach ze skupinek šestnáctiletých sedmnáctiletých 
romských kluků, kteří se potulují po městě. Mnoho lidí taky štve, když cestou do práce a z práce vidí denně před domy u autobusového nádraží vysmáté Romy na sociálních dávkách."

Zatímco obraz dlužníků jako obětí obchodu s chudobou nabývá pozitivních či negativních konotací se zdůvodněním dluhu, morální prezentace Romů byla závislá na způsobu vysvětlování jejich nezaměstnanosti. Absence zaměstnání je klíčová také pro figury neslušných chudých.

Součástí kategorií nezaměstnaných a nepřizpůsobivých byla představa, že bez jejich existence by obchod s chudobou vůbec neexistoval. Obě figury byly konstruovány jako obecné kondenzátory nemorálních vlastností, s nimiž se jejich sousedé a stát musejí potýkat. Pouze výjimečně však byly spojovány s konkrétními událostmi. Jsou zde však i důležité rozdíly. Nezaměstnaným byla připisována závislost na sociálních dávkách a poskytování špatných vzorů dětem, nepřizpůsobivým narušování veřejného pořádku, vandalismus, demolování či podpalování bytů a zodpovědnost za vznik sociálního napětí. Oproti nezaměstnaným nebyli nepřizpůsobiví definováni ani tak zahálkou, jako spíše prací na černo, čímž se měli dopouštět zneužívání sociálních dávek. A o to větší vinu měli na rozmachu obchodu s chudobou, nebot bez dávek na bydlení by si obchodníci nemohli účtovat vysoké nájmy.

Kromě zastírání strukturálních podmínek při vysvětlování obchodu s chudobou měli nezaměstnaní a nepřizpůsobiví funkci navozování představy obchodu s chudobou jako problému, v němž etnická příslušnost ubytovaných nehraje roli. Některá sdělení se však od tohoto př́istupu odchýlila. Příkladem je článek „Vesnici svírá strach. Bojí se i starosta“, kde starosta Josef Hálek prezentoval obchod s chudobou skrze konflikty obyvatel dvou vesnic s Romy a dělníky z východu, vzápětí nepřímo označovaných za nepřizpůsobivé (Právo 2017):

Doslova teror zažívají obyvatelé Semněvic na Domažlicku, kde kvete byznys s chudobou. [...] Potíže podle starosty vznikly zhruba před rokem, kdy se do Semněvic přistěhovala první problémová rodina. Zamířila do ubytovny, kterou vlastní žena žijící jinde. Stejné potíže se později objevily i v dalších dvou domech. Vedle Romů v nich žijí dělníci z východu. [...] Potíže s nepřizpo̊sobivými občany dlouhodobě mají i Janovice nad Úhlavou na Klatovsku.

\section{Důsledky}

Důsledky obchodu s chudobou byly analyzovány na třech úrovních: na úrovni klientů obchodu s chudobou, na úrovni občanského soužití mezi klienty a jejich sousedy a na úrovni činnosti veřejné správy. Důsledky pro klienty obchodu s chudobou se týkaly především možnosti nečekané ztráty domova, obývání nedostatečně velkých nebo nedi̊stojných prostorů, ohrožení sociálním vyloučením a v menší míře pak odebírání dětí, ztráty pracovních návyků a podvodů při platbě nájemného a energií.

Ztráta domova mohla být zpo̊sobena mnoha faktory: náhlým vystěhováním kvůli narušení bezpečnostních či hygienických standardů obývaných prostor, krátkým výpadkem v platbě nájemného nebo třeba politicky motivovaným omezením výplaty dávek na bydlení, která by řadě rodin způsobila finanční potíže. Tyto faktory byly navíc prezentovány v kontextu chudoby klientů, kteří nedisponovali finančními možnostmi pro přestěhování do jistějšího domova. Jako překážka byla uváděna také rozšířená diskriminace v nájemním bydlení, která v řešení situace brzdila i ty, kteří potřebnými penězi disponovali.

Důsledky pro klienty a tím i obchod s chudobou jako takový byly líčeny také v souvislosti s nedůstojnými ubytovacími prostory. Často byly v tomto př́ípadě používány pitoreskní popisy malých místností obývaných velkým počtem osob a se sdílenými toaletami a sprchovými kouty 
a nedostatečně vybavenými kuchyněmi. Vedle nedostatku soukromí pak bylo často upozorňováno na přítomnost obtížného hmyzu, jako jsou švábi či štěnice.

V omezené míře bylo zmiňováno i odebrání či hrozba odebrání dětí ze strany lokálních odborů sociálně-právní ochrany dětí, zdůvodňované nevyhovujícími podmínkami ubytovacích zařízení $\mathrm{k}$ výchově dětí. Ojediněle bylo psáno o podvodném či jiném nezákonném jednání ze strany obchodníků s chudobou. Nutno dodat, že k tomuto typu důsledků obchodu s chudobou byli povoláváni jako mluvčí mimo politiků také reprezentanti neziskových organizací, př́ípadně klienti, jejichž úkolem bylo autenticky zprostředkovat strádání.

Dlouhodobý pobyt $\mathrm{v}$ tomto prostředí byl traktován jako jedna z hlavních příčin vedoucí k sociálnímu vyloučení a doprovodným jevům jako apatie nebo rizikové chování. Tyto jevy byly připisovány především nehostinnému prostředí ubytoven, na nichž i podle jejich obyvatel panuje atmosféra přispívající k výraznému odchýlení se od společenských norem. To ilustruje např́íklad i výňatek ze článku „Brno rozdělilo padesáti rodinám bez domova byty. Komu, rozhodlo losování“, v němž obyvatelka brněnské ubytovny zmínila své psychické problémy i zkušenost s výchovou dcery v prostředí přeplněné ubytovny (ČT24 2016):

Na zhruba polovině z 80 brněnských ubytoven vypadá situace podobně. Této matce s dcerou po roční smlouvě v předchozím bydlišti neprodloužili nájem a skončila na ubytovně jménem Pohoda. Dva měsíce, které zde strávila, stačily k tomu, aby se psychicky zhroutila. „Veškeré návyky, které jsem se snažila dceři vštípit, jsou pryč. Bojím se o ni."

Soužití mezi klienty obchodníků s chudobou a jejich sousedy bylo rámováno hlavně sociálním napětím vyplývajícím ze zvýšené kriminality a migrace nepřizpůsobivých. Projevy problematického soužití byly prezentovány z hlediska zkušeností osob obývajících okolí míst, kde dochází k obchodu s chudobou, nebo informací lokálních politických představitelů, strážníků a policistů. Promluvy obyvatel byly založeny na strachu o svou bezpečnost a popisu sousedských sporů spíše než na konkrétních zkušenostech s kriminalitou. Oficiální představitelé se naproti tomu odkazovali spíše k drobné kriminalitě, jako jsou krádeže v obchodech, rušení nočního klidu či vandalismus, nebo ke stížnostem obyvatel. Pouze výjimečně byly ve výstupech uvedeny konkrétní údaje nebo srovnání s minulostí. V situacích, kdy byli jako mluvčí povoláváni strážníci či policisté, prezentované údaje zpravidla oponovaly „katastrofickému“ líčení místní situace obyvateli či politickými představiteli.

Zhoršení bezpečnostní situace bylo vztahováno k předpokládanému přistěhování problémových obyvatel ze všech regionů ČR a Slovenska. Co do své charakteristiky odpovídali migranti v zásadě figuře nepřizpůsobivých, která byla analyzována výše. Migrace však nebyla chápána jen ve smyslu přistěhování se neznámých a nebezpečných obyvatel do klidných obcí nebo částí měst. Byla prezentována také jako možný důsledek nejistého podniku, jimž obchod s chudobou je. At už proto, že obchodníci s chudobou mohou ze dne na den své nájemníky vystěhovat, anebo je jejich ubytovací zařízení zavřeno z rozhodnutí zodpovědných úřadů.

V souvislosti s migrací se ve veřejné rozpravě hovořilo i o cíleném stěhování rodin do míst zasažených socioekonomickou deprivací za účelem čerpání sociálních dávek. Někdy se tomuto procesu přezdívalo „sociální turistika“. Výňatek z článku „Byznys přerovských ubytoven kvete dál. Magistrátu navzdory“ (MF Dnes 2015a) tento proces ilustruje:

V Přerově si ted radnice např́íklad neví rady s tím, jak zastavit př́liv dlouhodobě nezaměstnaných lidí, kteří přicházejí z jiných měst. Manažer prevence kriminality a radní Jiří Kohout tvrdí, že je do Přerova paradoxně přitahuje vysoká nezaměstnanost. „Pro lidi, kteří se naučili zneužívat výhody sociálních dávek, je město s vysokou nezaměstnaností ideální. Nehrozí jim tady, že je někdo bude posílat do práce." 
Obchod s chudobou byl pojímán také jako fenomén rozprostírající před veřejnou správu celou řadu problémů, kterým je nutné čelit. Jednalo se především o narušování estetických norem, které je s podnikáním s chudobou bytostně spojeno, o finanční výdaje obcí a státu, které jsou na toto podnikání navázány, a také o kompetenční spory mezi obcí a státem týkající se péče o chudé.

Obchod s chudobou se podepisuje i na proměně vnímání veřejného prostoru. Proměna obnášela materiální i morální úpadek projevující se vybydlenými domy, zdemolovanými byty, obtížným hmyzem, odpadky na ulici a přítomností narkomanů. Tento popis byl obvykle dáván do kontrastu s minulostí místa př́ijemného k životu. Požadovaného obrazu veřejného prostoru bez známek chudoby mělo být dosaženo pomocí rekonstrukcí, vysídlení chudých, „nepřizpůsobivých“ a Romů, v nejzazším př́ipadě pak i demolicí postižených budov.

Estetika veřejného prostoru byla tematizována obvykle obyvateli povolanými k mediálnímu svědectví o poměrech v místech postižených obchodem s chudobou, případně lokálními politiky definujícími estetickou nápravu jako svůj politický cíl. Příkladem svědectví o proměně kdysi příjemného místa k životu v upadající městskou čtvrt je citace „starousedlíka“ v pořadu Máte slovo (С̌T 2015b):

Paní ministryně, to, co jste ted'kon řekla, není vůbec žádná pravda. Bydlím tam 30 let. Před 30 lety sídliště vypadalo krásně. Mělo celou infrastrukturu. Ted’ vám můžu ukázat zazděný baráky, vybydlený, zničený, nepřizpůsobivejma občanama, kteří dostávají dávky na bydlení. Jeden byt zničí, jdou do druhýho, jsou tam štěnice, jsou tam šváby $[$ sic $]$.

V souvislosti s obchodem s chudobou byly obce i stát často líčeny jako nositelé významných finančních nákladů. Náklady samosprávy představovaly zejména výdaje na opravu zanedbaných budov ohrožujících své nájemce či okolí, výkup ubytoven či jiných nemovitostí od obchodníků s chudobou za účelem změny jejich užívání, zajištění provozu sociálních služeb pro klienty obchodu s chudobou nebo zajištování bezpečnosti posílením činnosti strážníků v okolí nemovitostí apod.

Nepoměrně vyšší náklady měl nést stát. Především to bylo dáno rostoucími výdaji na doplatek na bydlení, údajně hlavní prostředek prŕíjmu obchodníků s chudobou. Využíván byl přitom tzv. institut zvláštního př́jemce, jenž umožňoval čerpat dávky př́imo, tj. bez přičinění jeho regulérních př́jemců. V této souvislosti bylo upozorňováno na to, že obchodníci s chudobou nenabízejí bydlení odpovídající vysokému nájemnému, ale bydlení nuzné a nedůstojné. Tento argument v roce 2014 zesílil po zveřejnění meziročního nárůstu částek vyplácených na příspěvky na bydlení, načež začal být obchod s chudobou již zcela explicitně charakterizován jako „vysávání státního rozpočtu“ a „miliardový byznys“. Výše vyplácených dávek na bydlení se postupem času stala jedním z klíčových argumentů přítomných ve většině analyzovaných sdělení. Dokládá to uvedení reportáže „Změny v sociálním bydlení" moderátorem pořadu Události (ČT 2017b):

13 miliard ročně, takové jsou výdaje státu na bydlení potřebných. Část dávek ale proudí přímo k majitelům ubytoven. Praxe, kterou už léta kritizují starostové i nevládní organizace.

Pod tuto podkapitolu lze zařadit i téma kompetenčních sporů mezi obcemi a státem. Toto téma se vynořilo ke konci sledovaného období v rámci debat o řešení problému obchodu s chudobou. Jádrem sporu se staly dva zákony, o jejichž podobu se přeli zástupci obcí, státu a neziskových organizací.

Obce byly v promluvách svých mluvčích pojímány jako oběti nevhodného nastavení zákona o hmotné nouzi. Proto požadovaly po vládě a státních institucích větší kompetence, které by jim dovolily vyplácení dávek na bydlení na svém území více regulovat a tím omezovat i obchod s chudobou. Vláda jim tuto kompetenci uložila v roce 2014 prostřednictvím novelizace zákona 
o hmotné nouzi a tzv. Stanjurova př́lepku, ${ }^{5}$ který však o rok později Ústavní soud posoudil jako neústavní. Stát prostřednictvím svých úředníků požadavky obcí později i uznával, ale problém rámoval jiným způsobem. Jako řešení byla stanovena finanční kompenzace za administraci péče o chudé obyvatele včetně vytvoření speciálních dotačních programů pro rozvoj sociálního bydlení, které by obcím umožnily tvořit vlastní politiku v této oblasti.

Tento spor se později stal součástí širší debaty o podobě sociálního bydlení v ČR, krystalizující kolem připravovaného zákona o sociálním bydlení. Zákon měl integrovat požadavky obcí ohledně vytvoření nástrojů pro regulaci vyplácení dávek na bydlení s požadavkem státu po aktivním přístupu obcí k řešení obchodu s chudobou a péče o chudé obyvatelstvo obecně. Ústředním bodem zákona se stala výstavba sociálních bytů pod kontrolou obcí, respektive míra závaznosti a vymahatelnosti tohoto opatření, otázka finančních nákladů a šîre cílové skupiny, jíž by měly být byty určeny.

Obce spíše odmítaly závaznost výstavby sociálních bytů, na které by údajně neměly peníze a které by musely poskytovat i těm, kteří si pomoc z veřejných peněz podle jejich názoru nezaslouží. Stát naproti tomu požadoval, aby sociální byty byly obcemi poskytovány za asistence nově vzniklých institucí jako Státní fond bytového rozvoje nebo vázanými dotačními programy. Cúlová skupina pak měla být co nejširší, bez ohledu na posuzování zásluhovosti žadatelů. Př́́kladem tohoto často tematizovaného sporu může být popis vyjednávání o podobě Zákona o sociálním bydlení, který přinesl deník MF Dnes (2017):

Sporné se jevily zejména dvě proměnné. Tou první je, kdo bude byty poskytovat. Dle koncepce to měly být obce a za neuposlechnutí hrozila milionová pokuta. Druhou ožehavou věcí se stala šíře cílové skupiny. V koncepci se mluvilo o statisících lidí, kteří by sítem prošli. V podstatě by šlo o kohokoli, kdo přijde o práci a př́ijem. Často ale i o rodinu s dětmi, kde jeden rodič má nadprůměrný plat a druhý je doma. Právě na šíri cílové skupiny si zakládala ministryně Marksová.

\section{Subjekty}

Subjekty obchodu s chudobou můžeme rozlišit do tří skupin: viníci, profitující a napravitelé. Za viníka i napravitele byly často označovány stát a obec. Obchod s chudobou totiž představuje výslednici dlouholetých politických a ekonomických procesů, do nichž tyto subjekty v různých obdobích různými způsoby vstupovaly a vzájemně na sebe působily. A právě časovost je tím, co jednotlivé subjekty odlišuje: viníkům byla připisována minulost, profitujícím př́tomnost a napravitelům blízká či vzdálená budoucnost.

\section{Viníci}

Za hlavní viníky obchodu s chudobou byly označovány obce a stát. Obce či jejich politická reprezentace se měly provinit tím, že po roce 1989 privatizovaly svůj bytový fond, který na ně byl převeden v období transformace ekonomiky z centrálně plánované na tržní. Tím vystavily obyvatele mnoha lokalit nekontrolovanému trhu se subjekty čekajícími na vhodnou příležitost k vlastnímu obohacení. Jako příklad takového obohacování bylo zmiňováno zejména odkupování chátrajících budov s cílem proměnit je na nízkonákladové bydlení pro chudé. Každopádně obce si

\footnotetext{
5 „Stanjurův přílepek“ označoval část ustanovení §33 odst. 6 zákona č. 111/2006 Sb., o pomoci v hmotné nouzi, ve znění zákona č. 252/2014 Sb., která ustavovala, že pro přiznání doplatku na bydlení bude třeba souhlas obce. Označení „Stanjurův př́lepek“ získala tato část podle poslance Zbyňka Stanjury (ODS), jenž ji prosadil do zákona na základě poptávky některých starostů obcí, na jejichž území se nacházely ubytovny pro chudé pobírající doplatek na bydlení (Vláda ČR 2015).
} 
privatizací bytového fondu samy omezily možnost rozhodovat, kdo na jejich území bude podnikat a bydlet.

Stát (vláda a parlamentní politici) se na rozvoji obchodu s chudobou podílel především zanedbáním politiky sociálního bydlení, které se projevovalo absencí zákona o sociálním bydlení a nákladnou výplatou dávek na bydlení. Absence zákona o sociálním bydlení, který by stanovoval práva a povinnosti státní správy a samosprávy v oblasti poskytování ubytování chudému obyvatelstvu, vytvořila situaci, kdy byla nejchudší část populace nucena vyhledávat ubytování na trhu s bydlením. Výše vstupních nákladů na úhradu kauce a několika prvních nájmů společně s rozššřenou diskriminací na trhu s bydlením pro Romy však z této části obyvatelstva vytvořila klientelu pro obchodníky s chudobou. Tento proces pak akcelerovalo zavedení dávek na bydlení v letech 1997 a 2007, jejichž výplata byla poměrně neurčitě podmíněna výší nájemného a kvalitou bydlení.

Na obce a stát coby viníky poukazovali v tomto smyslu především politici. Typickým př́kladem může být Michaela Marksová, jež v debatě „Zneužívání příspěvku na bydlení a sociální byty“ označila za viníky rozšiřrení obchodu s chudobou na litvínovském sídlišti Janov lokální politické představitele, kteří bytový fond sídliště odprodali soukromým subjektům, a zároveň stát, jenž tuto situaci podpořil vyplácením dávek na bydlení (ČT 2015b):

Ale já vám chci říct jednu věc. Janov, to sídliště, prodali vaši zastupitelé, ti samí částečně, kteří tam ted' chodí a pláčou, že jim tam soukromí majitelé, na které oni nemají vůbec žádný vliv v tuto chvíli, stěhují tyto lidi. A ano, máte pravdu, ten systém tak, jak je, je velice špatný, protože my těm lidem tam dáváme doplatky na bydlení, ale naprosto s nimi nepracujeme. A to je velmi špatné.

\section{Profitující}

Za profitující byli dosazováni obchodníci s chudobou, respektive majitelé či provozovatelé ubytoven, domů či jiných nemovitostí, ale i „spekulanti“, „,realitní kanceláře“ či „kšeftaři“. Ve všech případech byli obchodníci s chudobou prezentováni jako produkt státu, jehož zanedbání sociální politiky v oblasti bydlení umožnilo generovat miliardový zisk prostřednictvím lidí čerpajících dávky na bydlení. „Zneužívání sociálních dávek“ v tomto schématu spočívalo v nadsazování nájemného vzhledem $\mathrm{k}$ neodpovídajícímu stavu nemovitostí a obytných prostor, jehož výše byla často vyšší než v lukrativních částech města. Zobrazení principů podnikání obchodníka s chudobou nabídl starosta Velkých Hamrů v článku „Zeman chce zastavit obchod s chudobou“ (MF Dnes 2014a):

„Jeden člověk u nás pronajímá panelákový byt na sídlišti Romům na sociálních dávkách," podotýká hamrovský starosta Jaroslav Najman (Nezávislí). „V domě jsou kvůli nim konflikty. Majiteli bytu jsme nabízeli, že mu seženeme bezproblémové nájemníky, ale nechtěl. Ví dobře, že od nich nikdy nedostane za nájem tolik peněz jako od státu za lidi na sociálních dávkách."

Profitující obchodníci tak představovali figury nemorálně využívající pochybení obcí a státu a zranitelnosti svých klientů. Neomezovali se však pouze na „zneužívání dávek“, ale také se účastnili vydírání, když nabízeli odprodej svých nemovitostí za vysoké finanční částky.

Pokud v analyzovaných výstupech promlouvali profitující, vyjadřovali se především ke kvalitě nabízených nemovitostí a zisku, který z jejich podnikání plynul. Obchodníci s chudobou v těchto př́ipadech zaujímali defenzívní přístup: podle nich kvalita nemovitostí formálně splňovala nároky kladené státem a zisk z provozování „sociálního bydlení“ nebyl nikterak vysoký. Provozovatelé těchto nemovitostí navíc podle svých slov vycházeli vstříc i různým potřebám svých klientů. Takto např́íklad o svém podnikání hovořil provozovatel ubytovny v Ostravě (MF Dnes 2015b): 
Hotelový dům Hlubina přibližně dva roky provozuje Daniel Fatura. Odmítá, že by existoval byznys s chudobou. „Už nyní je zisk mnoha vlastníků minimální a smyslem podnikání je vytvářet zisk, nikoliv být na nule, " konstatoval a uvedl, že lidem zajištuje i služby, např́íklad praní. Samozřejmostí je ostraha. „Na druhou stranu žádáme absolutní dodržování provozního řádu, což se projevilo i na značném snížení kriminality,“ uvedl. Zdůraznil, že právě úřady jim dlouho sociálně slabé lidi posílaly.

\section{Napravitelé}

Napraviteli obchodu s chudobou byly opět míněny především stát a obce. Zatímco role státu a jeho reprezentace spočívala ve tvorbě účinné legislativy v oblasti sociálního bydlení a úpravy výplaty dávek na bydlení, které by omezily jejich „zneužívání“, potenciál obcí byl pojímán jako spíše malý. Budoucí zákon o sociálním bydlení byl ve sledovaném období prezentován vágně a odrážel spíše letitý spor státní správy a samosprávy o rozsah povinností v oblasti péče o chudé obyvatelstvo každého subjektu (srov. Rákosník, Tomeš a kol. 2012: 366-386; Jemelka 2018).

Konkrétněji se o roli státu hovořilo při zmínkách o regulaci vyplácení dávek na bydlení. Taková regulace měla být vázána na velikost pronajímaného prostoru a omezené období, během něhož by bylo možné dávku na bydlení čerpat. V př́ípadě velikosti měl stát zajistit, aby se výše dávek na bydlení vyplácených pronajímatelům bydlení nelišila od obvyklé výše nájemného v dané obci. Toho mělo být dosaženo především prostřednictvím tzv. cenových map a stanovení vyplácení dávek na $\mathrm{m}^{2}$. $\mathrm{V}$ případě omezeného období byl stát nabádán zejména ze strany představitelů obcí k přísnějšímu posuzování žádostí o dávky na bydlení, což by chudé obyvatelstvo motivovalo k usilovnějšímu hledání pracovních př́ležitostí, z nichž by si pak bydlení samo financovalo.

Obce byly představovány výrazněji jako subjekt, na jehož bedrech leží v současnosti největší tíha důsledků obchodu s chudobou. V této souvislosti byla zvláště lokálními politiky navrhována různá opatření k regulaci jeho infrastruktury, například stavební uzávěry na území obcí bránící výstavbě nových ubytoven, demolice nevyhovujících nemovitostí využívaných jako ubytovny, zajištování bezpečnostních, hygienických a stavebních standardů budov, kontrola způsobu udržování staveb, revize smluv se soukromými subjekty provozujícími na území obce ubytovny atp. Další opatření se týkala řešení důsledků obchodu s chudobou, od zavedení veřejné služby pro nezaměstnané a vymáhání dluhů přes kontrolu kriminality a veřejného pořádku až po regulaci hazardu nebo boj s drogami. Výjimkou se zde ke konci sledovaného období stalo město Brno, které se orientovalo především na poskytnutí části svého bytového fondu s cílem nabídnout klientům obchodníků s chudobou alternativní řešení jejich sociální situace.

Stát i obce se jako subjekty nápravy obchodu s chudobou objevovaly v mediálních výstupech obvykle pospolu. Příkladem takového výstupu je článek „Strach starostů: z chudých budou bezdomovci“" (Lidové noviny 2014):

O svá práva se však při tvorbě nových zákonů, která nastavují pravidla sociálního bydlení, hlásí i zmínění starostové. Naposledy úterní karvinskou konferencí, která si zvolila výřečný název „Důsledky parazitního způsobu života na bezpečnost v obcích“. V memorandu starostové z celého Česka například požadují, aby obce směly regulovat a kontrolovat provoz ubytovacích a sociálních zařízení. „A to dle stanovených cenových map se zohledněním a stanovením počtu ubytovaných osob vzhledem ke kapacitě zařízení (výměra $\mathrm{v} \mathrm{m}^{2} /$ vybavení/osoba), " usnesli se starostové. Jejich konference vyzývá vládu a poslance „k naléhavému řešení problematiky zákonnosti, bezpečnosti a sociálních problémů v obcích formou legislativních opatření a zajištění jejich výkonu". 


\section{Závěr}

V této studii jsme se pokusili ozřejmit, jak byl obchod s chudobou reprezentován ve výstupech českých zpravodajských médií v letech 2006 až 2017. Analýzou dat byla identifikována čtyři základní témata, na jejichž základě jsme vystavěli odpověd na naši výzkumnou otázku. Jednalo se o praktiky asociované s „obchodem s chudobou“, o jeho přímé či nepřímé oběti, o důsledky, které tento typ podnikání má, a konečně o subjekty, které tento fenomén různými způsoby utvářely. V této kapitole jsou hlavní zjištění shrnuta a interpretována s ohledem na dosavadní poznatky učiněné v zahraniční odborné literatuře a také naznačeny další směry výzkumu v domácím kontextu.

Praktiky obchodu s chudobou byly nadány pěti různými významy, přičemž si v něm konkurovaly zejména tyto dva: poskytování bydlení lidem pobírajícím sociální dávky na bydlení a poskytování vysokoúročených nebankovních půjček a následné vymáhání dluhů. Nejpozději od roku 2013 dominoval ten první z nich. Důvodem může být především symbolická síla ubytovny, ikonického místa ned i̊stojného bydlení a chudoby. Tyto významy odpovídají charakteru obchodu s chudobou, jak je popisován v zahraničních studiích. Jedná se o obohacování se mocnějších skupin obyvatel na úkor těch nejzranitelnějších, a to převážně za absence odporu na straně znevýhodněných, což má za následek další reprodukci chudoby. To dělá také z českého obchodu s chudobou klíčové téma pro kritickou kriminologii, nabízející vhodný konceptuální aparát k uchopení charakteristik tohoto fenoménu a právních rozporů, které ztělesňuje.

Obchod s chudobou ve svém dominantním významu, tj. poskytování bydlení lidem pobírajícím sociální dávky na ubytovnách, ale i v jiných nemovitostech nevhodných $\mathrm{k}$ dlouhodobému obývání, byl rámován třemi různými způsoby: jako parazitování, vykořistování nebo normální podnikání. Rozdíl mezi prvními dvěma pohledy se týkal vzniklé újmy. Zatímco parazitování způsobovalo újmu zejména státnímu rozpočtu, vykořistování ubližovalo především ubytovaným. Tyto pohledy se v mnoha mediálních výstupech prolínaly a byly čas od času konfrontovány kategorií „normální podnikání“. At už byli představováni jako jednotliví podnikatelé, nebo obchodní společnosti, aktéři tohoto podnikání se snažili neutralizovat obvinění z nemorálního jednání poukazem na nemorální způsob života svých klientů, spočívající v preferování života na dávkách namísto chození do práce. Pro zachování svého společenského postavení a tím i finančního profitu využívali obchodníci s chudobou diskurz „nepřizpůsobivosti“, který v minulosti vystavil nejzranitelnější část populace násilným demonstracím a represívním politikám nulové tolerance. Daný diskurz tedy přispívá i k rozvoji praktik, které mají pro ty, na něž je aplikován, závažné důsledky. Toto je však třeba spolu s technikami neutralizace obchodníků s chudobou dále zkoumat.

Nebyli to ale pouze klienti, obyvatelé žijící v substandardních podmínkách za nadsazené nájemné, kteří byli prezentováni jako oběti těchto podnikatelských praktik. Za oběti byly považovány také skupiny obyvatel poškozované obchodem s chudobou nepřímo, a to zhoršenou kvalitou života $\mathrm{v}$ místě bydliště nebo menším objemem sociálních dávek, které by v př́ípadě neexistence obchodu s chudobou mohly čerpat právě ony - ty skutečně potřebné. Obecně byly oběti charakterizovány jako chudé. Ekonomická nouze je spojovala, kdežto slušnost je naopak rozdělovala. Zatímco „slušné chudé“ zastupovali starousedlíci, senioři, matky samoživitelky, invalidé a nízkopříjmové rodiny, v roli „neslušných chudých“ vystupovali nezaměstnaní a nepřizpůsobiví. Vprostřed kontinua ne/slušnosti se nacházely figury dlužníků a Romů. Z hlediska kritické kriminologie jsou tyto hraniční figury důležité pro další výzkum v oblasti ne/rovnoměrného přístupu k právu u marginalizovaných skupin obyvatel. Naše studie ukázala, že i na spodních příčkách společenského žebřičku dochází k posuzování závažnosti nemorálních či přímo zločineckých praktik na základě představy o ideální oběti. Zdá se, že v českém kontextu je tato představa definována etnicitou a zadlužením. Tuto hypotézu je však také nutno ověřit.

Obchod s chudobou byl konstruován i skrze důsledky, které má pro své klienty, (občanské) soužití a veřejnou správu. Mezi hlavní důsledky pro klienty patřila hrozba nenadálé ztráty by- 
dlení, pobývání v nedůstojných podmínkách pro život a neustálá hrozba sociálního vyloučení. Tyto důsledky lze souhrnně označit jako prohlubování životní nejistoty. Důsledky pro soužití lze zase nazvat jako narušování sociálního řádu, kam spadala obava o bezpečnost, zvýšená kriminalita a migrace určovaná obchodem s chudobou. Z hlediska veřejné správy se mezi hlavní důsledky řadí: narušování estetiky veřejného prostoru cíleným podinvestováním pronajímaných nemovitostí, zvýšené finanční náklady spojené s kontrolou této infrastruktury a jejího okolí a kompetenční spory mezi státní správou a samosprávou, které praktiky obchodu s chudobou odhalily.

Obchod s chudobou byl tedy prezentován v tradici informování o občanském soužití mezi „problémovými Romy“ a „neproblémovými Neromy“, aniž by byla tato distinkce významně narušena. Na druhou stranu, tím, že je obchod s chudobou primárně orientován na nejzranitelnější část populace, byla tato hranice rozostřena informováním o konkrétních důsledcích pro přímé oběti obchodníků s chudobou, mezi něž patří i Romové. Z kriminologického hlediska představuje zajímavé zjištění, že mediální reprezentace obchodu s chudobou umožňuje tematizovat nejzranitelnější část populace nejen jako pachatele, ale také jako oběti.

Subjekty obchodu s chudobou lze rozlišit do tří skupin podle toho, zda tento obchod zavinily, nebo na něm profitují, anebo jej mají napravit. Viníky byly zpravidla obce, které v minulosti privatizovaly svůj bytový fond, čímž částečně přišly o možnost rozhodovat, kdo na území obcí bude podnikat, bydlet a za jakých podmínek. Dále to byl stát, který prostřednictvím svých institucí nedokázal stanovit důstojné a transparentní parametry péče o chudé obyvatelstvo. Souhra těchto dvou okolností dala vzniknout specifickému podnikání orientovanému na chudé obyvatelstvo, jehož ikonickými protagonisty se stali obchodníci s chudobou. Ti profitovali zejména skrze tzv. zneužívání sociálních dávek, respektive jejich př́ijmu v rámci nájemného v prostorech neodpovídajících cenou kvalitě bydlení. Obce a stát byly povolávány i jako subjekty, které by obchod s chudobou měly minimálně regulovat, anebo zcela vymýtit. Za hlavní nástroj omezování obchodu s chudobou pak byly prezentovány legislativa v oblasti sociálního bydlení a hmotné nouze v př́ípadě státu a kontrolní opatření a hledání alternativních možností u obcí. Obecně tedy lze říct, že subjekty nebyly tematizovány prostřednictvím kategorie kriminality, ale spíše prostřednictvím špatných či nedostatečných politických rozhodnutí a nemorálnosti.

Na základě naší analýzy lze říci, že obchod s chudobou představuje velmi politizované téma, které se primárně orientuje na využívání sociálních dávek v kontextu plateb za nevyhovující a nepřiměřeně drahé bydlení. Tato reprezentace upozaduje jiné praktiky, které byly zmíněny nejen v mediálních sděleních, ale také ve výzkumných zprávách (např. kriminální aktivity poskytovatelů bydlení). Praktiky poskytovatelů bydlení jsou tedy chápány spíše v rovině morální než trestněprávní. Právě tato distinkce zasazuje téma do oblasti zájmu kritické kriminologie, která upozorňuje na mocenské asymetrie v kriminalizaci určitého jednání. Zatímco kriminální jednání obyvatel ubytoven či sociálně vyloučených lokalit, kde je obchod s chudobou provozován, je často ve veřejném diskurzu tematizováno, kriminalita obchodníků s chudobou zde téměř absentuje. A zatímco řešení problémů sociálního vyloučení mají nezrrídka charakter represívních opatření vůči obyvatelům, řešení problému obchodu s chudobou je nejčastěji prezentováno především na úrovni legislativní, a jehož jediným efektem je, že obchodníci s chudobou mohou přijít o svůj př́ijem. Pouhá regulace plateb za bydlení přitom navíc může znamenat, že klienti obchodníků s chudobou o bydlení přijdou bez náhrady.

Dalším zajímavým poznatkem je, že přes důraz na socioekonomickou rovinu obchodu s chudobou a jeho klientů je etnokulturní dimenze neopominutelnou součástí této problematiky. Obchod s chudobou se stal jedním ze způsobů, jak mluvit o Romech a sociálních problémech s nimi spojovaných, aniž by se celé téma rámovalo jako „romská otázka“. To se ukazuje nejen v konstrukci obětí, ale také $\mathrm{v}$ případě prezentace důsledků obchodu s chudobou, především na úrovni 
občanského soužití. Ostatně také řada stereotypů příznačných pro nepřizpůsobivé je historicky spjatá s dominantními představami o Romech.

Důležitá je rovněž skutečnost, že se v průběhu sledovaného období kladl stále větší důraz na otázku politického řešení obchodu s chudobou. To odráží především sekce důsledků pro veřejnou správu a napravitelů problému. Pro obě je klíčové systémové hledisko, které řešení obchodu s chudobou prezentuje jako záležitost intervence do systému sociálního zabezpečení a rozšiření kompetencí obcí. S klienty a šířeji obětmi se v tomto ohledu v podstatě nepočítá, jsou chápáni jako pasivní objekty, které se přizpůsobí změně systémových podmínek. Na nejobecnější úrovni lze tedy mediální diskurz o obchodu s chudobou vnímat jako vyjednávání výkonu státní moci nad nejzranitelnějšími částmi populace.

\section{Financování}

Tento text vznikl v rámci výzkumného projektu „Bezpečnostní rizika sociálně vyloučených lokalit: Vytváření znalostí a nástrojů pro management a prevenci kriminality" (VI20152018022) podpořeného Ministerstvem vnitra ČR - Programem bezpečnostního výzkumu České republiky v letech 2015-2020 (BV III/1-VS).

\section{Bibliografie}

ASZ (Agentura pro sociální začleňování). 2014a. Průběžná zpráva o bezpečnostnich rizicích v sociálně vyloučených lokalitách za druhé pololetí 2013. Úřad vlády ČR: Agentura pro sociální začleňování.

ASZ (Agentura pro sociální začleňování). 2014b. Prưběěná zpráva o bezpečnostnich rizicích v sociálně vyloučených lokalitách za první pololetí 2014. Praha: Úřad vlády ČR, Agentura pro sociální začleňování.

Bryman, A. 2004. Social Research Methods. Second Edition. New York: Oxford University Press.

ČRo (Český rozhlas). 2016. „Byznys s chudobou po Česku. V Brně mohou zanedlouho skončit stovky lidí na ulici." [online] Český rozhlas: Radio Wave, 15. 11. 2016 [cit. 14. 8. 2018]. Dostupné z: https://wave.rozhlas.cz/byznys-s-chudobou-po-cesku-v-brne-mohou-zanedlouho-skoncit-stovky-lidina-ulici-5188974.

ČRo (Český rozhlas). 2018. „Za exekuce může byznys s chudobou. V̌řitelé by měli být zodpovědnější." [online] Český rozhlas: Host Radiožurnálu, 5. 3. 2018 [cit. 14. 8. 2018]. Dostupné z: https:// www.clovekvtisni.cz/co-delame/socialni-prace-v-cr/za-exekuce-muze-byznys-s-chudobouveritele-by-meli-byt-zodpovednejsi-radi-daniel-hule-4936gp.

ČT (Česká televize). 2015a. „Začleňování národnostních menšin.“ ČT1. Máte slovo, 11. 3. 2015.

ČT (Česká televize). 2015b. „Zneužívání příspěvku na bydlení a sociální byty. “ ČT1. Máte slovo. 22.1. 2015.

ČT (Česká televize). 2016. „Sociální byty v Brně." ČT1. Události v regionech, 15. 6. 2016.

ČT (Česká televize). 2017a. „Akutně je ohroženo ztrátou bydlení kvůli nedostatečným příjmům přes čtvrt milionu občanů." ČT1. Máte slovo, 18. 5. 2017.

ČT (Česká televize). 2017b. „Změny v sociálním bydlení.“ ČT1. Události, 11. 4. 2017.

ČT24. 2016. „Brno rozdělilo padesáti rodinám bez domova byty. Komu, rozhodlo losování." [online] Česká televize, 15. 6. 2016 [cit. 15. 8. 2014]. Dostupné z http://www.ceskatelevize.cz/ct24/regiony/1817585brno-rozdelilo-padesati-rodinam-bez-domova-byty-komu-rozhodlo-losovani.

DeKeseredy, W. S. 2010. Contemporary Critical Criminology. London: Routledge.

Denikreferendum.cz. 2017. „Jak nebojovat s chudobou." [online] Deník Referendum, 20. 10. 2017 [cit. 14. 8. 2018]. Dostupné z: http://denikreferendum.cz/clanek/26313-jak-nebojovat-s-chudobou.

Dvořáková, I. 2010. „Obsahová analýza / formální obsahová analýza / kvantitativní obsahová analýza." Antropowebzin 6 (2): 95-100.

Dvořáková, T. 2015. Situačni analýza města Slaný ve Středočeském kraji. Praha: Agentura pro sociální začleňování.

Echo24. 2016. „,Byznys na ubytovnách řešíme. Marksová odmítá Babišovu ,nehoráznost:" [online] Echo24, 8. 9. 2016 [cit. 14. 8. 2018]. Dostupné z: https://echo24.cz/a/wyNfp/byznys-na-ubytovnach-resimemarksova-odmita-babisovu-nehoraznost.

Engels, F. 1950. Postavení dělnické tř́dy v Anglii. Praha: Svoboda. 
Forman, J., L. Damschoder. 2008. „Qualitative Content Analysis.“ Pp. 39-62 in L. Jacoby (ed.). Empirical Methods for Bioethics: A Primer. Oxford: Elsevier.

Friedrichs, D. O. 2009. Trusted Criminals: White Collar Crime In Contemporary Society. Belmont: Wadsworth

Hall, S. 1997a. „Introduction.“ Pp. 1-12 in S. Hall (ed.). Representation: Cultural Representations and Signifying Practices. London: SAGE Publications.

Hall, S. 1997b. „The Work of Representation.“ Pp. 13-74 in S. Hall (ed.). Representation: Cultural Representations and Signifying Practices. London: SAGE Publications.

Happer, C., G. Philo. 2013. „The Role of the Media in the Construction of Public Belief and Social Change." Journal of Social and Political Psychology 1 (1): 321-336, https://doi.org/10.5964/jspp.v1i1.96.

Hatcher, D. L. 2016. The Poverty Industry: The Exploitation of America's Most Vulnerable Citizens. New York; London: New York University Press.

Hudson, M. (ed.) 2002. Merchants of Misery: How Corporate America Profits from Poverty. Monroe, Me: Common Courage Press.

Christie, N. 1986. „The Ideal Victim." Pp. 17-30 in E. A. Fattah (ed.). From Crime Policy To Victim Policy. London: The MacMillan Press.

iDnes. 2014. „Byznys s chudobou stojí Česko miliardu měsíčně. Živí pouze spekulanty. “ [online] iDnes.cz, 24. 8. 2014 [cit. 15. 8. 2018]. Dostupné z: http://bydleni.idnes.cz/socialni-bydleni-0k7-/ dum_osobnosti.aspx?c=A140819_160443_dum_osobnosti_web.

iDnes. 2018a. „Výsledek obchodu s chudobou v Jirkově: v domě není teplá voda, nebude teplo. " [online] iDnes.cz, 20. 3. 2018 [cit. 14. 8. 2018]. Dostupné z: https://usti.idnes.cz/odpojeni-energii-spekulantibytovy-dum-jirkov-obchod-s-chudobou-pxq-/usti-zpravy.aspx?c=A180315_389467_usti-zpravy_vac2.

iDnes.cz. 2018b. „Obchodníci s bídou mají nový fígl, lidi z ghett stěhují do jiných částí obce." [online] iDnes.cz, 11. 4. 2018 [cit. 14. 8. 2018]. Dostupné z: https://ekonomika.idnes.cz/najem-socialni-davkydoplatky-ghetta-chudoba-byznys-f91-/ekonomika.aspx?c=A180410_103620_ekonomika_ane.

Jedináková, H., J. Pischová. 2013. Zpráva o ubytovnách na Ostravsku aneb Jsou ubytovny opravdu vhodným řš̌ením pro bydlení rodin s dětmi a lidí bez domova? Ostrava: Vzájemné soužití.

Jemelka, M. 2018. „Od hornických kolonií po ghetta (rozhovor s Petrem Kupkou)." [online] A2larm.cz [cit. 14. 8. 2018]. Dostupné z: https://a2larm.cz/2018/02/od-hornickych-kolonii-po-ghetta/.

Katz, M. B. 2013. The Undeserving Poor: America's Enduring Confrontation with Poverty. Second Edition. Fully Updated and Revised. Oxford: Oxford University Press.

Kraj Vysočina. 2012. „Zpráva o stavu romské menšiny v kraji za rok 2012." [online] Kraj Vysočina [cit. 11.8. 2018]. Dostupné z: http://extranet.kr-vysocina.cz/samosprava/soubory/rada/materialy/2013/ 13/RK-13-2013-71pr01.doc.

Kupka, P., Brendzová, A., Walach, V., Plachý, O., Toušek, L., Lupták, L., Tvrdá, K., Vanková, K. 2018. "Obchod s chudobou: obsahová analýza českých médií v období 2006-2017." Středoevropské politické studie 20 (2), 124-146, https://doi.org/10.5817/CEPSR.2018.2.124.

Lidové noviny. 2014. „Strach starostů: z chudých budou bezdomovci." Lidové noviny, 4. 10. 2014.

Lind, H., G. Blomé. 2012. „Slumlords in the Swedish welfare state: how is it possible?" International Journal of Housing Markets and Analysis 5 (2), 196-210, https://doi.org/10.1108/17538271211225931.

MF Dnes (Mladá fronta Dnes). 2006. „Jak dostat romské děti do škol.“ Mladá fronta Dnes - Jižní Morava, 27. 6. 2006.

MF Dnes (Mladá fronta Dnes). 2007a. „Není cigán jako cigán.“ Mladá fronta Dnes, 12. 4. 2007.

MF Dnes (Mladá fronta Dnes). 2007b. „Gól do vlastní branky." Mladá fronta Dnes - Plzeňský kraj, 29.3.2007.

MF Dnes (Mladá fronta Dnes). 2014a. „Jizerskohorský továrník Zeman chce zastavit byznys s chudobou.“ Mladá fronta Dnes - Liberecký kraj, 15. 9. 2014.

MF Dnes (Mladá fronta Dnes). 2014b. „Lidé v Tanvaldu se bojí ghetta.“ Mladá fronta Dnes - Liberecký kraj, 29. 5. 2014.

MF Dnes (Mladá fronta Dnes). 2015a. „Byznys přerovských ubytoven kvete dál. Magistrátu navzdory.“ Mladá fronta Dnes - Olomoucký kraj, 11. 8. 2015.

MF Dnes (Mladá fronta Dnes). 2015b. „Lidé z ubytoven: Ženou nás do vězení." Mladá fronta Dnes Moravskoslezský kraj, 31. 10. 2015.

MF Dnes (Mladá fronta Dnes). 2017. „Boj o střechu nad hlavou." Mladá fronta Dnes, 16. 1. 2017.

Payne, B. K. 2017. White-Collar Crime: The Essentials. Second Edition. London: Sage. 
Pelikánová, A., M. Šmoldas. 2014. Zmapování kapacit bydlení využivaného k ubytovávání sociálně znevýhodněných v obci Větřní s důrazem na soukromé ubytovny. Praha: Agentura pro sociální začleňování.

Právo. 2017. „Vesnici svírá strach. Bojí se i starosta." Právo - jihozápadní Čechy, 5. 5. 2017.

Procter, J. 2004. Stuart Hall: Routledge Critical Thinkers. London: Routledge.

Rada vlády ČR. 2012. Zpráva o stavu romské menšiny za rok 2011. Praha: Rada vlády pro záležitosti romské menšiny.

Rada vlády ČR. 2015. „Zpráva o stavu romské menšiny za rok 2014.“ [online] Rada vlády pro záležitosti romské menšiny [cit. 14. 8. 2018]. Dostupné z: https://www.vlada.cz/cz/ppov/zalezitosti-romskekomunity/dokumenty/zprava-o-stavu-romske-mensiny-za-rok-2014-136688/.

Radostný, L., H. Štěpánková, D. Vališ. 2015. Situační analýza obce Př̌́bram. Praha: Agentura pro sociální začleňování.

Rákosník, J., I. Tomeš a kol. 2012. Sociální stát v Československu: Právně-institucionální vývoj v letech 1918-1992. Praha: Auditorium.

Saussure, F. de. 2007. Kurs obecné lingvistiky. Třetí vydání v nakladatelství Academia. Praha: Academia.

Soederberg, S. 2014. Debtfare States and the Poverty Industry: Money, Discipline and the Surplus Population. London; New York, NY: Routledge, Taylor \& Francis Group.

Sutherland, E. H. 1940. „White-Collar Criminality.“ American Sociological Review 5 (1): 1-12, https:// doi.org/10.2307/2083937.

Týden. 2013. „Předlice na odstřel.“ Týden, 19. 9. 2013.

Uitermark, J., M. Loopmans. (2013). „Urban renewal without displacement? Belgium's ,housing contract experiment" and the risks of gentrification." Journal of Housing and the Built Environment 28 (1), 157-166, https://doi.org/10.1007/s10901-012-9299-0.

Vašíčková, A. 2017. „Sociální pomoc v oblasti bydlení. Dávky na bydlení." [online] Veřejný ochránce práv [cit. 14. 8. 2018]. Dostupné z: https://www.ochrance.cz/fileadmin/user_upload/projekt_ESF/ 01_01_MIMOPROJEKTOVE/10_19_a_20_JH/Davky_na_bydleni.pdf.

Vláda ČR. 2014. „Programové prohlášení Vlády ČR." [online] Vláda ČR [cit. 14. 8. 2018]. Dostupné z https://www.vlada.cz/cz/media-centrum/dulezite-dokumenty/programove-prohlaseni-vladycr-115911/.

Vláda ČR. 2015. „Novela zákona o hmotné nouzi čeká na opětovné projednání poslanci.“ [online] Vláda $\check{C} R$ [14. 8. 2018]. Dostupné z: https://www.vlada.cz/cz/clenove-vlady/pri-uradu-vlady/jiridienstbier/aktualne/novela-zakona-o-hmotne-nouzi-opet-pred-poslanci-132679/.

Walach, V. 2016. Význam bezpečnosti v sociálně vyloučené lokalitě. Nepublikovaná disertační práce. Brno: Fakulta sociálních studií, Masarykova univerzita.

White, M. D., E. E. Marsh. 2006. „Content Analysis: A Flexible Methodology. " Library Trends 55 (1): $22-45$.

\section{O autorech}

Petr Kupka, Václav Walach, Alica Brendzová, Ondřej Plachý, Lubomír Lupták, Laco Toušek, Kateřina Tvrdá, Klára Vanková a Tereza Dvořáková tvořili v letech 2015-2018 kolektiv BRIZOLIT, který působil na Katedře antropologie Fakulty filozofické Západočeské univerzity v Plzni. V tomto období realizovali výzkum „Bezpečnostní rizika sociálně vyloučených lokalit: Vytváření znalostí a nástrojů pro management a prevenci kriminality (BRIZOLIT)“, který se zaměřil na viktimizaci související se sociálním vyloučení. Jeho cílem bylo poskytnout první ucelený obraz o viktimizaci, kriminalitě a bezpečnosti v sociálně vyloučených lokalitách prostřednictvím výzkumu mezi obyvateli těchto lokalit a vnějšími aktéry, kteř́ do této problematiky vstupují. Výsledky tohoto výzkumu byly dosud publikovány v monografii Labyrintem chudoby a zločinu: kriminalita a viktimizace v sociálně vyloučených lokalitách (Doplněk, 2018) a v odborných časopisech Demografie, Sociólogia, Středoevropská politická studia a Politologická revue.

\section{Summary}

In recent years, the poverty business has become a firm part of public discourse and has also made its way into government documents. Despite its political relevance, however, this term has yet to be properly examined; this term has been used in many different senses in various research reports. None of them, 
however, attempted to define it. This study aims to remedy this shortcoming. Because we are convinced that it is the media in which the term is increasingly used at present, this is where we have decided to base our research.

The study asks the following question: How was the poverty business represented in the period from 2006 to 2017? The study has been conceived as exploratory research with the aim of contributing to research on the significance of the poverty business and fostering other research in this field. Media information was analyzed with the help of the Anopress IT database. The corpus was made up of 1277 articles and a total of 66 texts were incorporated into the analysis. These were news media of varying geographical focus, type, periodicity, and ownership. The information was analyzed using a qualitative content analysis, which we understand as a method of identifying and analyzing the key topics for the given context.

By analyzing the data, four main themes were identified. Based upon these, we formulated the answer to our research question. The four themes included practices associated with the "poverty business", its direct and indirect victims, the consequences of this type of business, and finally the entities that this phenomenon has created in various manners.

Five various meanings were attributed to the practices of the poverty business, in which the following two dominated: firstly, the provision of accommodation for people collecting housing benefits, and secondly the provision of high-interest, non-bank loans and the subsequent debt collection. The former dominated until 2013 at the latest. The prime reason for this may be the symbolic power of lodging houses, iconic locations of undignified housing and poverty. The poverty business in the sense of providing accommodation to individuals collecting housing benefits in lodging houses and other immovable property unsuitable for long-term habitation has been framed in three different ways: parasitizing, exploitation, and normal business.

Victims were considered to be clients living in sub-standard conditions for exaggerated rents, and groups of people indirectly harmed by the poverty business via the lowered quality of life where they live or the low amount of social welfare that they - the truly needy - might be collecting if it were not for the poverty business. Victims were characterized in general as poor and differing in terms of decency or indecency.

Consequences were analyzed in three areas: consequences for clients, interethnic coexistence, and the public administration. The consequences for clients were: the threat of sudden loss of housing, living in undignified conditions, and the constant threat of social exclusion. Consequences for interethnic coexistence included concerns about safety, increasing crime, and migration dictated by the poverty business. The primary consequences for the public administration included the disruption of the aesthetics of public space via disinvestment of rented properties, increased financial costs required to monitor the infrastructure and its surroundings, and jurisdiction disputes between state and local authorities.

The entities of the poverty business can be divided into three groups according to whether they caused the existence of the poverty business themselves, profit from it, or are meant to remedy it. Guilty parties were often municipalities, which in the past privatized their housing stock and partially lost the possibility to make decisions on who would do business and/or live in the municipality and under what conditions. The other guilty party was the state, which did not manage to establish dignified and transparent parameters for the care of its poor population. The ones who profited were the poverty entrepreneurs, profiting from the business by "abusing" social welfare payments or accepting them in the form of rent in areas in which rent prices did not correspond to the quality of housing. The municipalities and the state were called upon also as the entities that should at least regulate the poverty business or do away with it altogether. The main tool presented for curbing the poverty business was legislation in the area of social housing and material poverty in the case of the state and monitoring measures and the search for alternative options in the case of the municipalities. 
Přiloha č. 1: Seznam vybraných mediálních sdělení

\begin{tabular}{|c|c|c|c|}
\hline Název článku & Autor & Médium & Datum \\
\hline Jak dostat romské děti do škol & Ivana Svobodová & MF Dnes - jižní Morava & 27.9 .2006 \\
\hline Gól do vlastní branky & neuveden & MF Dnes - Kraj plzeňský & 29.3. 2007 \\
\hline Není cigán jako cigán & Krystyna Wanatowiczová & Mladá fronta Dnes & 12. 4.2007 \\
\hline Jak se parazituje na „parazitech“ & Tomáš Hirt & Mladá fronta Dnes & 22.5 .2007 \\
\hline $\begin{array}{l}\text { Exekuce sociálních dávek jsou } \\
\text { palivem kšeftu s chudobou }\end{array}$ & Roman Krištof & $\begin{array}{l}\text { Mladá fronta Dnes - Jižní } \\
\text { Morava }\end{array}$ & 12. 12.2007 \\
\hline Obchodují s chudobou & Tomáš Hirt & $\begin{array}{l}\text { Olomoucký deník - } \\
\text { Spotřebitelský úděl }\end{array}$ & 6.3 .2008 \\
\hline $\begin{array}{l}\text { Koncert: Protidluhovou kampaň } \\
\text { podpoří skupiny Jolly Joker, Zima } \\
\text { a Fly To Mars }\end{array}$ & Radek Strnad & Ústecký deník & 1. 4.2008 \\
\hline $\begin{array}{l}\text { Skupují zdevastované domy } \\
\text { a vydělávají na chudých }\end{array}$ & Miroslav Brož & Mladá fronta Dnes & 19. 6.2008 \\
\hline $\begin{array}{l}\text { Romská otázka v českých a } \\
\text { evropských politických kulisách }\end{array}$ & & Český rozhlas 6 & 15.4 .2009 \\
\hline Varování ze Slovenska & Ivan Gabal & Mladá fronta Dnes & 3.9. 2010 \\
\hline $\begin{array}{l}\text { Napětí na Šluknovsku mají řešit } \\
\text { těžkooděnci }\end{array}$ & Hana Škodová & Hospodářské noviny & 24.8.2011 \\
\hline $\begin{array}{l}\text { Obchod s chudobou je } \\
\text { lukrativní... }\end{array}$ & Kateřina Březová & www.vasevec.cz & 30.8 .2011 \\
\hline $\begin{array}{l}\text { Je vymáhání drobných pohledávek } \\
\text { nemorálním podnikáním? }\end{array}$ & Miroslav Uričař & www.ceskapozice.cz & 1. 2.2012 \\
\hline $\begin{array}{l}\text { Klienti? Převážně oběti } \\
\text { obchodování s chudobou }\end{array}$ & Barbora Němcová & $\begin{array}{l}\text { Mladá fronta Dnes - } \\
\text { plzeňský kraj }\end{array}$ & 29. 3. 2012 \\
\hline Koukejte se přizpůsobit! & Tomáš Urban & zpravy.idnes.cz & 21. 7.2012 \\
\hline Přednádraží za nádražím & Martin Škabraha & www.denikreferendum.cz & 9.8 .2012 \\
\hline Katapult k chudobě & Marcela Alföldi Šperkerová & Euro & 1. 10.2012 \\
\hline $\begin{array}{l}\text { Podnikatelé s chudobou vydělávají } \\
\text { na ubytovnách v chudinských } \\
\text { čtvrtích }\end{array}$ & & ČRo-Sever & 29.11. 2012 \\
\hline Předlice na odstřel & Robert Malecký & Týden & 25.2.2013 \\
\hline $\begin{array}{l}\text { Český anticiganismus aneb Zpráva } \\
\text { o stavu země }\end{array}$ & František Kostlán & www.denikreferendum.cz & 20.3. 2013 \\
\hline Bezpečnost & & Radiožurnál & 26.9 .2013 \\
\hline $\begin{array}{l}\text { Rasismus a vztahy k menšinám } \\
\text { v České republice }\end{array}$ & & Radiožurnál & 3. 10.2013 \\
\hline $\begin{array}{l}\text { Jak z parlamentu zmírníte sociální } \\
\text { napětí a jak zabráníte zneužití } \\
\text { dávek? }\end{array}$ & (ula) & $\begin{array}{l}\text { Mladá fronta Dnes - } \\
\text { severní Čechy }\end{array}$ & 15. 10.2013 \\
\hline Fungování sekce pro lidská práva & & С̆T24 & 21. 10. 2013 \\
\hline $\begin{array}{l}\text { Ubohé kšefty s chudobou } \\
\text { nezatrhne jediný zákon }\end{array}$ & Marie Kudrnovská & Haló noviny & 11. 12.2013 \\
\hline $\begin{array}{l}\text { Návrh programového prohlášení } \\
\text { vlády Bohuslava Sobotky }\end{array}$ & ČTK & zpravy.idnes.cz & 10. 2.2014 \\
\hline Vláda: Programové prohlášení & vlada.cz & www.parlamentnilisty.cz & 11. 2.2014 \\
\hline $\begin{array}{l}\text { O osudu Podhoranu rozhodnou } \\
\text { obyvatelé Bystřice v anketě }\end{array}$ & Petra Procházková & $\begin{array}{l}\text { Mladá fronta DNES - } \\
\text { Zlínský kraj }\end{array}$ & 28.3. 2014 \\
\hline
\end{tabular}




\begin{tabular}{|c|c|c|c|}
\hline & & \multicolumn{2}{|c|}{ (pokračováni z předchozi strany) } \\
\hline $\begin{array}{l}\text { Bílá mr*ko, podpálím ti barák, } \\
\text { křičel podle Okamury muž. Šéf } \\
\text { Úsvitu jel „dělat pořádek“ do } \\
\text { vesnice, starostka ho nevítala }\end{array}$ & jno & www.parlamentnilisty.cz & 31. 3. 2014 \\
\hline $\begin{array}{l}\text { Vyjádření hnutí Úsvit k zákonu } \\
\text { o exekutorech a hmotné nouzi }\end{array}$ & $\operatorname{sih}$ & protext.cz & 6.5 .2014 \\
\hline $\begin{array}{l}\text { Sociální napětí: Do Šluknova } \\
\text { dorazila část vlády }\end{array}$ & & www.denik.cz & 12.5 .2014 \\
\hline Ministři na Šluknovsku & & ČT1 & 12.5 .2014 \\
\hline $\begin{array}{l}\text { Ministři si prohlédli ubytovny na } \\
\text { Šluknovsku, chtěli by zamezit } \\
\text { byznysu s chudobou }\end{array}$ & & ČRo-Sever & 13.5 .2014 \\
\hline Lidé v Tanvaldu se bojí ghetta & Miloslav Lubas & $\begin{array}{l}\text { Mladá fronta Dnes - } \\
\text { Liberecký kraj }\end{array}$ & 29.5 .2014 \\
\hline $\begin{array}{l}\text { Na bydlení chudým dává stát } \\
\text { miliardu měsíčně }\end{array}$ & Zuzana Kubátová & Mladá fronta Dnes & 18. 8.2014 \\
\hline $\begin{array}{l}\text { Byznys s chudobou stojí Česko } \\
\text { miliardu měsíčně. Živí pouze } \\
\text { spekulanty }\end{array}$ & & www.idnes.cz & 24. 8. 2014 \\
\hline $\begin{array}{l}\text { Jak nejlépe vyřešit otázku } \\
\text { sociálních ubytoven? }\end{array}$ & & Nové Přerovsko & 5.9. 2014 \\
\hline $\begin{array}{l}\text { Ubytovny a jejich obyvatelé. Klíč k } \\
\text { srdcím ostravských voličů? }\end{array}$ & Petra Sasínová & CT24.cz & 10.9. 2014 \\
\hline $\begin{array}{l}\text { Jizerskohorský továrník Zeman } \\
\text { chce zastavit byznys s chudobou }\end{array}$ & Miloslav Lubas & $\begin{array}{l}\text { Mladá fronta Dnes - } \\
\text { Liberecký kraj }\end{array}$ & 15. 9.2014 \\
\hline $\begin{array}{l}\text { Strach starostů: z chudých budou } \\
\text { bezdomovci }\end{array}$ & Kateřina Eliášová & Lidové noviny & 4. 10.2014 \\
\hline Romské rodiny míří na jih Čech & & ČT1 & 19. 11.2014 \\
\hline $\begin{array}{l}\text { Zneužívání příspěvku na bydlení a } \\
\text { sociální byty }\end{array}$ & & ČT1 & 22.1 .2015 \\
\hline Začleňování národnostních menšin & & ČT1 & 11. 3.2015 \\
\hline Ve jménu chudoby & & Květy & 4. 6.2015 \\
\hline $\begin{array}{l}\text { Kumar Vishwanathan: Stát a } \\
\text { města si berou chudé lidi za své } \\
\text { rukojmí. Je to na ústavní stížnost }\end{array}$ & voj & www.romea.cz & 8.6. 2015 \\
\hline $\begin{array}{l}\text { Vyhánění lidí z ubytoven na ulici } \\
\text { začíná }\end{array}$ & František Kostlán & www.denikreferendum.cz & 17. 6.2015 \\
\hline $\begin{array}{l}\text { Radnice zatrhla vyplácení dávek. } \\
\text { Obchod s chudobou v Bystřici } \\
\text { končí }\end{array}$ & Petra Procházková & $\begin{array}{l}\text { Mladá fronta DNES - } \\
\text { Zlínský kraj }\end{array}$ & 25.6 .2015 \\
\hline $\begin{array}{l}\text { Byznys přerovských ubytoven } \\
\text { kvete dál. Magistrátu navzdory }\end{array}$ & Petra Klimková & $\begin{array}{l}\text { Mladá fronta Dnes - } \\
\text { Olomoucký kraj }\end{array}$ & 11. 8.2015 \\
\hline $\begin{array}{l}\text { Lidé z ubytoven: Ženou nás do } \\
\text { vězení }\end{array}$ & Josef Gabzdyl & $\begin{array}{l}\text { Mladá fronta Dnes - } \\
\text { Moravskoslezský kraj }\end{array}$ & 31.10 .2015 \\
\hline Zemana inspiruje Skandinávie & $\mathrm{mh}$ & Haló noviny & 28.12 .2015 \\
\hline $\begin{array}{l}\text { MPSV počítá v novele se snížením } \\
\text { doplatku na bydlení v ubytovnách }\end{array}$ & & epravo.cz & 19. 2.2016 \\
\hline $\begin{array}{l}\text { Na bydlení na ubytovnách přispěje } \\
\text { stát méně. Vláda schválila snížení } \\
\text { doplatku }\end{array}$ & ČTK & aktualne.cz & 7. 4.2016 \\
\hline
\end{tabular}




\begin{tabular}{|c|c|c|c|}
\hline & & \multicolumn{2}{|c|}{ (pokračováni z předchozi strany) } \\
\hline $\begin{array}{l}\text { Brno rozdělilo padesáti rodinám } \\
\text { bez domova byty. Komu, rozhodlo } \\
\text { losování }\end{array}$ & spickovap & CT24.cz & 15.6 .2016 \\
\hline Sociální byty v Brně & & ČT1 & 15. 6.2016 \\
\hline $\begin{array}{l}\text { Martin Šimáček host Interview } \\
\text { Plus }\end{array}$ & & Čro Dvojka & 21. 6.2016 \\
\hline Nový zákon o sociálním bydlení & & ČT1 & 9.9.2016 \\
\hline $\begin{array}{l}\text { Sociální byty mají zachránit } 5000 \\
\text { rodin }\end{array}$ & Stáňa Sedová, Jan Martinek & Právo & 6. 10.2016 \\
\hline $\begin{array}{l}\text { Dienstbier přednášel necelé } \\
\text { dvacítce studentů v Plzni }\end{array}$ & Václav Fiala & parlamentnilisty.cz & 23. 11. 2016 \\
\hline Boj o střechu nad hlavou & & Mladá fronta Dnes & 16. 1.2017 \\
\hline $\begin{array}{l}\text { Ministr Chvojka spolu se zástupci } \\
\text { Agentury pro sociální začleňování } \\
\text { a monitorovacího výboru navštívili } \\
\text { pracovně Most }\end{array}$ & voj, adg, ČTK & www.romea.cz & 30.1. 2017 \\
\hline $\begin{array}{l}\text { Sokolov čelí přílivu sociálně } \\
\text { slabých lidí. Co s tím? }\end{array}$ & Redakce & denik.cz & 31. 3. 2017 \\
\hline Změny v sociálním bydlení & & ČT1 & 11. 4.2017 \\
\hline $\begin{array}{l}\text { Kontroly vyloučených lokalit v } \\
\text { Mostě }\end{array}$ & & ČT1 & 25. 4. 2017 \\
\hline $\begin{array}{l}\text { Vesnici svírá strach. Bojí se i } \\
\text { starosta }\end{array}$ & Jan Švábek & Právo - jihozápadní Čechy & 5.5 .2017 \\
\hline $\begin{array}{l}\text { „Migranti tam vůbec nejsou, } \\
\text { neříkejte mi nesmysly," zpražila } \\
\text { Marksová starostu Aše, který u } \\
\text { Jílkové přednesl své obavy }\end{array}$ & $\mathrm{mp}$ & parlamentnilisty.cz & 18. 5.2017 \\
\hline $\begin{array}{l}\text { Akutně je ohroženo ztrátou } \\
\text { bydlení kvůli nedostatečným } \\
\text { př́ímům přes čtvrt milionu občanů }\end{array}$ & & ČT1 & 18.5. 2017 \\
\hline
\end{tabular}

